\title{
Silicon in the Soil-Plant Continuum: Intricate Feedback Mechanisms within Ecosystems
}

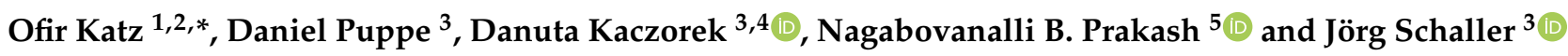 \\ 1 Dead Sea and Arava Science Center, Mt. Masada, Tamar Regional Council, 86910 Tamar, Israel \\ 2 Eilat Campus, Ben-Gurion University of the Negev, Hatmarim Blv, 8855630 Eilat, Israel \\ 3 Leibniz Centre for Agricultural Landscape Research (ZALF), 15374 Müncheberg, Germany; \\ daniel.puppe@zalf.de (D.P.); Danuta.Kaczorek@zalf.de (D.K.); Joerg.Schaller@zalf.de (J.S.) \\ 4 Department of Soil Environment Sciences, Warsaw University of Life Sciences (SGGW), 02776 Warsaw, Poland \\ 5 Department of Soil Science and Agricultural Chemistry, University of Agricultural Sciences, GKVK, \\ Bangalore 560065, India; nagabovanalliprakash@rediffmail.com \\ * Correspondence: katz.phyt@gmail.com; Tel.: +972-522-885563
}

Citation: Katz, O.; Puppe, D.;

Kaczorek, D.; Prakash, N.B.; Schaller, J. Silicon in the Soil-Plant Continuum Intricate Feedback Mechanisms within Ecosystems. Plants 2021, 10, 652. https://doi.org/10.3390/ plants10040652

Academic Editor: Wolfgang Schmidt

Received: 14 February 2021

Accepted: 26 March 2021

Published: 30 March 2021

Publisher's Note: MDPI stays neutral with regard to jurisdictional claims in published maps and institutional affiliations.

Copyright: (C) 2021 by the authors. Licensee MDPI, Basel, Switzerland. This article is an open access article distributed under the terms and conditions of the Creative Commons Attribution (CC BY) license (https:// creativecommons.org/licenses/by/ $4.0 /)$.

\begin{abstract}
Plants' ability to take up silicon from the soil, accumulate it within their tissues and then reincorporate it into the soil through litter creates an intricate network of feedback mechanisms in ecosystems. Here, we provide a concise review of silicon's roles in soil chemistry and physics and in plant physiology and ecology, focusing on the processes that form these feedback mechanisms. Through this review and analysis, we demonstrate how this feedback network drives ecosystem processes and affects ecosystem functioning. Consequently, we show that Si uptake and accumulation by plants is involved in several ecosystem services like soil appropriation, biomass supply, and carbon sequestration. Considering the demand for food of an increasing global population and the challenges of climate change, a detailed understanding of the underlying processes of these ecosystem services is of prime importance. Silicon and its role in ecosystem functioning and services thus should be the main focus of future research.
\end{abstract}

Keywords: silicon; soil; plants; cycling; ecosystem; services; feedback

\section{Introduction}

Silicon (Si) uptake and accumulation is a functional trait with multiple implications for plant biology and ecology [1,2]. Silicon's manifold functions in plant biology include protection from a myriad of abiotic and biotic stresses and confers many benefits to plants that are capable of taking up and accumulating large amounts of it, ranging from practically zero in some taxa to $5 \%$ dry weight (and in extreme cases even more) in grasses [1,3-17], and probably even to those plants that take up considerably smaller amounts [5,18]. Moreover, its uptake from the soil and eventual reincorporation into the soil through plant litter and herbivore feces also affects soil properties and Si cycling [19-23]. Thus, Si uptake, accumulation and cycling by plants is a key phenomenon in many ecosystems [12,21,24-26], with direct and indirect implications for ecosystem properties and processes [1]. Here, we review the existing knowledge of $\mathrm{Si}$ in the soil-plant continuum, its roles in plant biology and ecology, in ecosystem processes, and the possible implications for various ecosystem services.

\section{Historical Overview}

In 1787, Antoine Lavoisier predicted the existence of the element $\mathrm{Si}$, to which $\mathrm{Sir}$ Humphry Davy proposed the name "silicon" in 1808. It was eventually isolated and formally discovered in 1823 by Jöns Jacob Berzelius. The discovery of the occurrence of $\mathrm{Si}$ within plants quickly followed, owing to the works of some prominent scholars, including microscopy pioneer Christian Gottfried Ehrenberg (who suggested the word "phytolitharia" to describe plant mineral components) [27] and Charles Darwin, who provided him with 
some samples $[28,29]$. Silicon effects on plant performance are known for more than 170 years, starting with Struve in 1835 [30], and shortly after Davy's pioneering publication from 1846, who suggested that $\mathrm{Si}$ is present in the epidermis of grasses, where it strengthens the plants and makes them more resistant to attacks by insects and "parasitical plants" [31]. A surge of research soon followed. Sachs [32] showed in 1862 that Si-accumulating plants were a less preferred food than their conspecific plants that were grown hydroponically in Si-poor media. He further found that $\mathrm{Si}$ accumulation started in plant hairs and further advanced into the epidermis and near leaf vascular tissues. He also suggested that not all $\mathrm{Si}$ deposits in plant leaves are hard, but some may remain in a colloidal state. Miliarakis [33] found in 1884 that basal (younger) leaf parts of Si-accumulating plants had lower Si concentrations than older leaf tips and could not deter feeding. He also found that horsetail (Equisetum) and sedge (Carex and Scirpus) old leaf sheaths had a high Si concentration and protected the younger and less silicified plant tissues from herbivory. Furthermore, in 1884, Kreuzhage and Wolff [34] suggested the importance of Si for oat plants. Kerner von Marilaun [35] suggested in 1887 that the sharp leaf margin of sedges may be due to $\mathrm{Si}$ deposits. In 1888, Stahl [36] summarized other studies and concluded that silica deposits in horsetails impeded grazing by snails. He also mentioned that plant tissue silicification reduced the food quality of tropical grasses in Africa for domestic animals.

A second surge of studies started in the 1920s. Between 1922 and 1925, Lemmermann and colleagues [37-39] found an increase in the yield of rye grown under phosphorus deficiency upon Si fertilization. Sommer [40] concluded in the year 1926 that rice plants without Si fertilization suffered from early increased leaf wilting, guttation, and retarded panicle formation. In parallel, a surge of studies on Si effects on rice took place in Japan, starting in the 1910s and continuing into the 1940s, summarized thoroughly by Ma and Takahashi [41]. In the 1910s, Onodera [42] found that blast-infected rice leaves had a lower Si concentration than healthy leaves. Miyake et al. [43] also found in 1922 that Si concentration was higher in blast-resistant plants than nonresistant (surprisingly, this specific Japanese research was published in German). Other studies showed an increased blast-resistance of rice plants following Si application [44,45]. In the 1930s Ishibashi [46-48] showed reduced growth and yield of rice plants under Si deficiency and reduced blast after Si fertilization. Raleigh [49] showed in 1939 that Si was strongly improving the growth of beet plants. A year later, Wagner [50] showed that Si protects plants against powdery mildew by silicifying host plants' cell walls, hence reducing penetration.

The study of silicon in plants continued shortly following the end of World War II, and especially since the 1960s. Engel [51] found in 1953 that the Si accumulated in rye culm was $\sim 1 / 3$ easily (hot water) extractable, suggesting no strong binding of this fraction to the plant cell walls. Holzapfel and Engel [52] found that $\mathrm{Si}$ accumulation in wheat increases over a study period of 30 days. In 1962, Yoshida [53] discovered the cuticle-Si double layer and suggested that this layer may be responsible for plant resistance against fungal diseases. There were several publications by Okuda and Takahashi, who found that $\mathrm{Si}$ improves plant resistance to metals [54] and rice growth and nutrition of [55]. Many of these studies were reviewed by Lewin and Reimann at the end of the 1960s [56]. During the same period, Jones and his colleagues (mainly Handreck) published some seminal papers on the occurrence, uptake, localization and functions of $\mathrm{Si}$ in oats [57-60] and clover [61]. At around the same time, a group that developed around Parry and his successor Sangster (both of which have passed away only in the past decade in their $90 \mathrm{~s}$ ) further looked into the physiology of Si uptake and deposition [62-71]. Their early studies set the basis for a greater effort in Si plant and soil research, and a third surge that started in the 1980s and continues to these days, initiated by many important scientists and continuing to these days by the many who follow their footsteps.

\section{Soluble and Particulate Silicon in the Soil}

This section provides a short overview of the different forms of $\mathrm{Si}$ in soils and the main drivers for Si availability for plants. A more elaborate review of Si occurrence forms, 
speciation and cycling in soils is provided by Schaller et al. [26] in another manuscript published within this Special Issue.

Silicon occurs in many forms in the soil. The solid forms of soil $\mathrm{Si}$ include crystalline forms of primary (e.g., quartz, feldspars, micas) and secondary silicate minerals (e.g., the different clay minerals), as well as microcrystalline or poorly crystalline minerals (e.g., allophane, imogolite, opal-CT) [72,73]. Amorphous silica (ASi) includes both Si of mineralogical origins that is included in pedogenic oxides (e.g., iron oxides) and biogenic Si (e.g., phytoliths) [72,73]. All these can undergo dissolution, under various conditions and rates, to become the source of dissolved plant-available monosilicic and polysilicic acids $\left(\mathrm{H}_{4} \mathrm{SiO}_{4}\right.$, jointly termed "silicic acid" hereafter) [72] with a maximum solubility of $\sim 1 \mathrm{mM}$. Both acids, in turn, may adsorb to soil particles (e.g., Fe or Al oxides/hydroxides) [72,74,75]. Polysilicic acid is mobilized during the dissolution of Si-rich solids [76], whereas at equilibrium Si in solution occurs as monosilicic acid [77]. However, at the early stages of dissolution, the presence of polymeric species may account for approximately $50 \%$ (by mol) of total dissolved silica [76]. Polysilicic acid converts over time to monosilicic acid if the concentration is far below saturation, but with increasing silicic acid concentrations in solution, the polymerization of monosilicic acid to polysilicic acid occurs. Nevertheless, silicic acid in soil solution is not only available for plant uptake and can precipitate but may also bind to (secondary) minerals [75]. The absorption of polysilicic acid to mineral surfaces is much faster than the sorption of monosilicic acid and is reversible; therefore, monosilicic acid is more abundant in soil porewaters than polysilicic acid [78]. In a study of soils from Karnataka, southern India, ASi was found to be the most abundant soil Si fraction, whereas silicic acid and adsorbed Si were the least abundant [79], and that high soil ASi contents are often associated with high contents of the clay size fraction [79,80], both a consequence of long-term primary silicate dissolution and plant activity.

\subsection{Silicic Acid Effects on Nutrient and Toxicant Availability in Soils}

Although silicic acid is competing with nutrients for binding to soil mineral surfaces [81-83], Si fertilization has been suggested to increase plant $P$ status by potentially increasing $P$ availability $[84,85]$. A recent study showed that increasing Si availability in soils leads to a mobilization of $\mathrm{Fe}(\mathrm{II})-\mathrm{P}$ phases from mineral surfaces, thus increasing $\mathrm{P}$ availability/mobility in soils [83]. Silicic acid can be assumed to be a non-charged bidentate ligand at soil $\mathrm{pH}<7$ [86]. Thus, $\mathrm{pH}$ has a strong influence on soil $\mathrm{Si}$ availability $[79,87]$. The monosilicic acid molecule is in direct competition for sorption sites with the monodentate and bidentate (depending on $\mathrm{pH}$ ) ligands of the phosphate molecule [88]. Despite having weaker binding energy to iron oxides than phosphate [86], silicic acid may outcompete phosphate if its concentration in pore water is sufficiently high. Another important property of silicic acid is that it can polymerize at high concentrations both in solution and on iron oxide surfaces forming Si-O-Si oligomer chains [89,90]. The binding affinity of polysilicic acid seems to be higher than monosilicic acid [76]. This may explain why silicic acid at higher concentrations is able to outcompete phosphate at binding sites of soil minerals. A further effect of $\mathrm{Si}$ in soils is the occupation of soil binding sites by an excess of silicic acid preventing nutrient binding to soil mineral surfaces [88].

Not only nutrients like $\mathrm{P}$ and $\mathrm{N}$ are mobilized from soils by $\mathrm{Si}$ [81,91], but also potentially toxic metals and metalloids (e.g., $\mathrm{Al}, \mathrm{Cr}, \mathrm{Cd}, \mathrm{Pb}$ and $\mathrm{Zn}$ ) [81] that impair plant performance if taken up [92]. However, less is known about how silicic acid potentially mobilizes metals and metalloids from different soil minerals. It is known that high $\mathrm{pH}$ Si fertilizers (such as fly ash or steel slag) decrease metal availability due to changing metal speciation and/or increased precipitation [93]. The bioavailability of aluminum may be reduced by Si fertilization owing to instant binding of Al to Si $[26,94,95]$ to form hydroxyl aluminosilicates [96]. Such a co-precipitation with $\mathrm{Si}$ was also suggested for $\mathrm{Cr}$, $\mathrm{Cd}, \mathrm{Pb}$ and $\mathrm{Zn}$ [97-99]. However, it was shown that $\mathrm{Cr}$ immobilization by binding to iron minerals was reduced after pretreatment of the iron minerals with silicic acid [100]. Hence, in systems with high $\mathrm{Si}$ availability, ASi precipitations on mineral surfaces potentially act 
as a long-term hindrance for immobilization of toxic metals and metalloids as the binding of those toxic elements to mineral surfaces may be blocked [88].

\subsection{Amorphous Silica as Control for Water Availability in Soils}

Some literature claimed that ASi increases soil water holding capacity [73,88,101], possibly via silica gel formation from polysilicic acid or colloidal ASi [102]. A recent study showed that ASi strongly increases soil water holding capacity and availability for plants [103]. An increase of 1\% or 5\% ASi (by weight) increased the water content at any water potential and plant-available water by up to $40 \%$ or $60 \%$, respectively [103]. However, a comprehensive picture of the effect of ASi content on the water holding capacity of soils is still missing.

\section{Silicon Uptake by Plants}

\subsection{Active Uptake by Intrinsic Transporters}

Plant taxa vary in the amounts of Si they take up and accumulate, a variability that is manifested through variations in Si contents, uptake mechanisms, forms and deposition locations. Traditionally, plant taxa have been divided into three major types based on their Si uptake capabilities, defined by the amounts of Si taken up by the plant (often measured as $\mathrm{Si}$ content in the xylem) relative to the amounts of available $\mathrm{Si}$ in the soil solution. If the amount of $\mathrm{Si}$ in the plant is considerably larger than that in the soil solution, the plant takes up Si actively; if the amount of $\mathrm{Si}$ in the plant is considerably lower than in the soil solution, the plant excludes $\mathrm{Si}$; if the two contents are comparable, the plant takes up Si passively [104]. As straightforward as this division is, it is over-simplified and lacks mechanistic rigor.

For once, the reference to available Si content in the soil solution can be misleading since the great variability of soil Si pools implies that a species may take up Si both actively and passively, depending on the soil type and parent material. A dynamic approach is more appropriate since it indicates the plant's response to varying soil Si availabilities and can furthermore point to the underlying internal (physiological) drivers of such responses [7,16]. For example, some species seem to increase their active Si uptake when Si availability in the soil is lower, suggesting an active response to fulfill plant internal Si demands when passive uptake is insufficient $[105,106]$. In some cases, this is achieved by increasing the expression of Si transporter genes and the density of these transporters under low Si availability conditions [16], indicating a truly active uptake that does not only rely on active uptake mechanisms but also on physiological responses of these mechanisms. Furthermore, Si uptake also depends on transpiration rates, with some species demonstrating passive (transpiration-driven) Si uptake in addition to active (transporter-governed) Si uptake [105-107]. The modes and drivers of Si uptake and accumulation and its variability among species are, therefore, not as simple as an active/passive/exclusion division implies.

Several transporters and genes that are involved in Si uptake and accumulation have been studied so far. Although the study of Si transporters focuses on rice and other grasses (as is commonly the case in plant Si research $[5,18]$ ), the first plant gene to regulate Si accumulation was discovered in the gourd Cucurbita (Cucurbitaceae), regulating Si and phytolith formation in the fruit rind [108]. Shortly after, a surge of discoveries of the physiology and genetics of Si uptake in grasses has arisen, revolving around the four Lsi transporters, all belonging to the NIP aquaporin family. The first transporter to be discovered was the influx transporter Lsi1, located in the distal plasma membrane of root exodermis and endodermis cells [109]. An efflux transporter on the proximal plasma membrane of the same cells, Lsi2, transports Si from the exodermis to the cortex and further loads it from the endodermis onto the xylem [110]. A third transporter, Lsi6, exists in the shoots and is responsible for xylem offloading [111]. In grass shoot nodes, Lsi6 and Lsi3 (previously thought to be Lsi2 due to structural similarities) are involved in distributing Si among branches [112-115]. Together, these transporters constitute an elaborate cooperative 
system of Si uptake and distribution in grasses, with some variations in the details of where exactly each transporter is localized within each species $[16,112,116]$ (Figure 1).

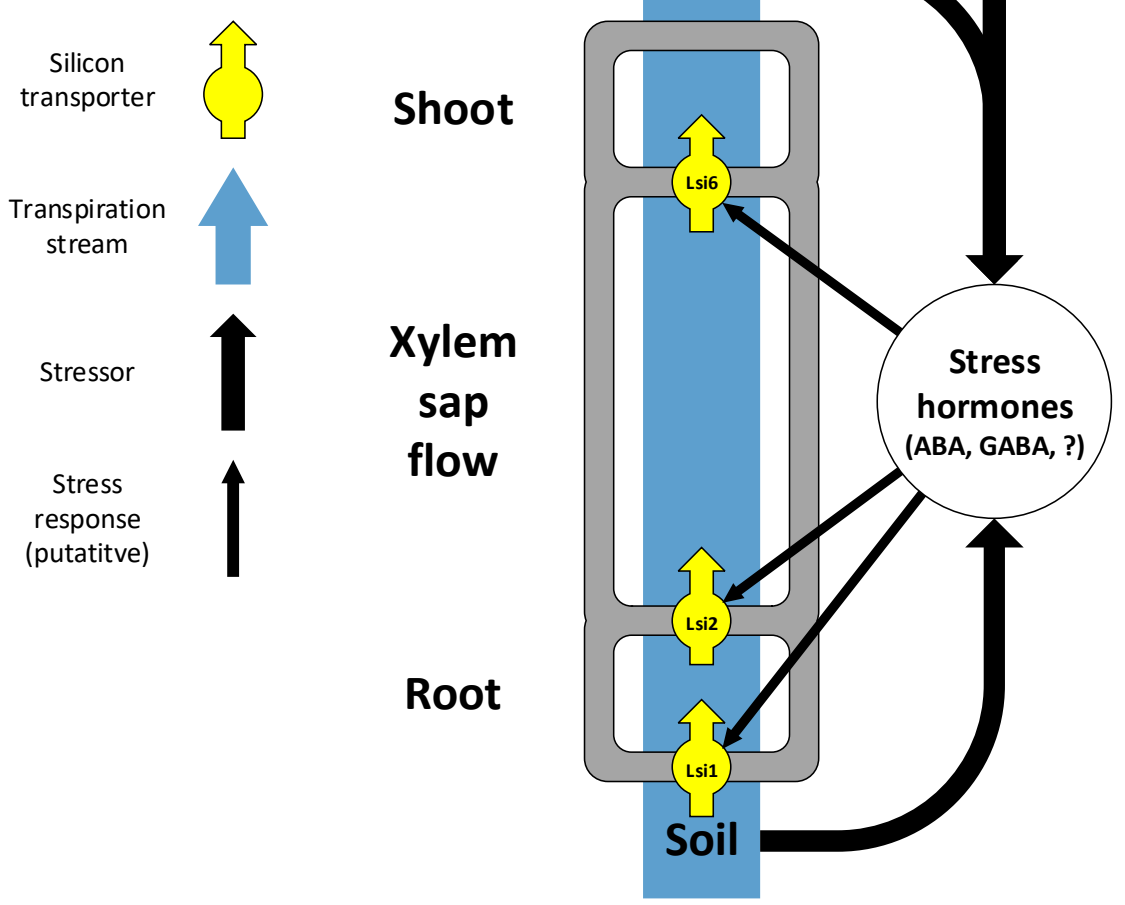

Figure 1. A simplified model of Si uptake from the soil to the shoot through the transpiration stream, including main transporters and responses to external factors.

Lsi1 and Lsi6 transporters were also identified in the soybean Glycine max [117]. In the Cucurbitaceae, a Si-accumulating dicotyledonous family, Lsi1 was also identified in all root cells of Cucurbita [118]. Wang et al. [119] identified two putative Si transporters in cucumber (Cucumis) of the same family. Together with the early-identified gene responsible for Si accumulation in Cucurbita rinds [108], these studies suggest that Si transport systems in grasses and dicotyledons share some similarities. The recent identification of a gene regulating Si uptake by the mangrove Rhizophora apiculate without identifying the transporter itself [120]. Multiple genes regulating Si uptake and accumulation were also found in the horsetail Equisetum arvense [121]. Finally, it appears that Lsi-like genes that govern Si uptake are common in many groups of land plants, suggesting that the origins of these mechanisms are as ancient as the origins of land plants [122]. These findings further suggest that the physiology and genetics of Si transporters in non-grass species are only beginning to reveal themselves.

Expression of the Lsil gene in rice is downregulated by Si supply, dehydration stress and abscisic acid (more strongly in Si-depleted plants), suggesting regulation of active Si uptake in response to changes in the transpiration stream and plant internal water balance [123]. Further studies have demonstrated how the expression of Lsi1, Lsi2 and Lsi6 genes is regulated by plant hormones [124] and internal Si and metal concentrations [125,126].

\subsection{External Factors Affecting Silicon Uptake}

In addition to intrinsic transporters, external factors also affect $\mathrm{Si}$ uptake and accumulation in plants. These include both passive uptake mechanisms driven by the transpiration stream (the soil-plant-air continuum; Figure 1) and active mechanisms induced or enhanced by biotic stressors. Since $\mathrm{Si}$ is taken up from the soil as monosilicic acid within the soil solution, 
passive Si uptake depends on the transpiration stream. Several studies have shown that plant Si content in grasses increases with soil water content and availability, most probably for the simple reason that the more water a plant absorbs, the more $\mathrm{Si}$ is taken up with it [127-133]. On the other hand, transpiration, acting as the motive force of water uptake, has also been shown to increase Si content in grasses, to the degree that $\mathrm{Si}$ content has been suggested to serve as an indicator to plant transpiration stress [113,133-137]. Hence, along large rainfall gradients, Si content tends to demonstrate a U-shaped curve (minimum Si content at approximately 200-300 mm mean annual rainfall), implying an interplay between water availability and transpiration motive force $[134,136]$. Nevertheless, high plant $\mathrm{Si}$ contents in extremely arid conditions may also occur because grasses under drought stress take up $\mathrm{Si}$ more actively for the benefit it confers in resisting drought or in herbivore deterrence (see Section 5 below) $[134,136,137]$. Nevertheless, the failure to observe this positive correlation in other studies of grasses $[138,139]$ suggests that other variables may confound the simple positive effect of water availability [134,136] (For Si effects on soil water availability co-appearing with Si availability in soils, see Section 3.2 above). In the Asteraceae family, an intermediate Si accumulator with mostly passive Si uptake (as far as we know, no attempts were made so far to identify Si transporters in this family), there appears to be no clear, consistent pattern, suggesting that $\mathrm{Si}$ uptake is not simply driven by the transpiration stream $[134,136]$. That the expression of the Lsi1 gene in rice is down-regulated by dehydration stress and abscisic acid [123] is a further indication for the complex effects of the transpiration stream on Si uptake.

Several studies have shown that ambient $\mathrm{CO}_{2}$ concentrations also affect plant $\mathrm{Si}$ uptake, content and form, but with contradictory results. Ambient $\mathrm{CO}_{2}$ concentrations had no effect on root and shoot $\mathrm{Si}$ contents in sugarcane plants [140]. In rice, increased ambient $\mathrm{CO}_{2}$ concentrations reduced husk $\mathrm{Si}$ deposition by as much as $60 \%$ [141]. Increased ambient $\mathrm{CO}_{2}$ concentrations alter the composition of phytolith assemblages in Phragmites and reduce mean phytolith size [142], suggesting an effect on Si allocation and distribution. Despite these studies being limited and equivocal regarding the regulatory role of $\mathrm{CO}_{2}$ on plant Si uptake and accumulation, they harness potential significance for our understanding of global Si-carbon relationships, namely the possibility of Si being a partial substitute for carbon in plants (see Section 5 below) and Si's role in regulating the carbon cycle (see Section 6 below).

Among the biotic stressors known to affect plant Si content, herbivory is the one that was studied the most [143]. Exposure to invertebrate [144-147] and vertebrate [144,148] herbivores induces $\mathrm{Si}$ uptake and accumulation in grasses. Comparable induction by artificial clipping [149-151] further supports that this induction is directly associated with biomass removal or damage. While such induction was sometimes not observed in controlled experiments [144,151-155], this is likely because these experiments did not incorporate sufficiently long exposure times to initiate a response [134,144]. In natural landscapes, higher grass $\mathrm{Si}$ contents are associated with larger densities of herbivorous rodents [154,156-159], but not of larger herbivores [137,148,160] or following clipping [151], which is most likely explained by the involvement of other environmental variables in natural ecosystems having stronger effects on Si uptake and accumulation [134]. Nevertheless, recent evidence for cyclic dynamics of vole densities and grass Si contents $[157,159,161]$ provides further support to the induction of grass Si uptake by herbivory. Among the Asteraceae, the only non-grass family in which the possible effect of herbivory on Si has been widely studied, such an effect was rare and weak [137].

\section{The Variability of Silicon in Plants}

\subsection{Methods for Extracting Si from Plant Material}

There are several methods to quantify plant $\mathrm{Si}$ concentration. We describe the six most used methods hereinafter (Table 1), all starting from ground plant material. The easiest extraction method is the method using a $1 \% \mathrm{Na}_{2} \mathrm{CO}_{3}$ solution [80,162-164], first developed 
by DeMaster [165]. For this method, $30 \mathrm{mg}$ plant material is extracted in a $1 \% \mathrm{Na}_{2} \mathrm{CO}_{3}$ solution for $5 \mathrm{~h}$ at $85^{\circ} \mathrm{C}$, afterward filtered $(0.45 \mu \mathrm{m})$ and analyzed.

Table 1. Summary of main plant Si extraction and measurement techniques.

\begin{tabular}{|c|c|c|}
\hline Extractant & Procedure & Reference \\
\hline $1 \% \mathrm{Na}_{2} \mathrm{CO}_{3}$ solution & \multirow{6}{*}{$\begin{array}{l}\sim 30 \mathrm{mg} \text { plant material extracted in } 1 \% \mathrm{Na}_{2} \mathrm{CO}_{3} \text { solution at } 85^{\circ} \mathrm{C} \\
\sim 100 \mathrm{mg} \text { plant material extracted in } 0.5 \mathrm{M} \mathrm{NaOH} \text { solution at } 85^{\circ} \mathrm{C} \\
\text { Step 1: } \sim 100 \mathrm{mg} \text { plant material digested in a mixture of distilled water, nitric } \\
\text { acid and hydrofluoric acid }(40 \%) \text { at } 190^{\circ} \mathrm{C} \\
\text { Step 2: hydrofluoric acid is neutralized by } 10 \mathrm{~mL} \text { a } 4 \% \text { boric acid solution at } \\
\qquad 150{ }^{\circ} \mathrm{C} \\
\text { Plant material ashed at } 500{ }^{\circ} \mathrm{C} \text {. The ash is mixed with lithium } \\
\text { meta-tetraborate at } 1000^{\circ} \mathrm{C} \text {. The obtained bead is transferred into nitric acid. } \\
\text { Plant material added to tiron solution buffered at pH } 10.5 \text { at } 85^{\circ} \mathrm{C} \text {. } \\
\sim 100 \mathrm{mg} \text { plant material homogenized to a powder, but calibration } \\
\text { is required. }\end{array}$} & {$[162,165]$} \\
\hline $0.5 \mathrm{M} \mathrm{NaOH}$ solution & & [162] \\
\hline 2-step HF & & [166] \\
\hline Lithium metaborate fusion & & {$[167,168,171]$} \\
\hline Tiron $\left(\mathrm{C}_{6} \mathrm{H}_{4} \mathrm{Na}_{2} \mathrm{O}_{8} \mathrm{~S}_{2}\right)$ & & [169] \\
\hline No extractant, but XRF & & [170] \\
\hline
\end{tabular}

The second method is comparable easy and uses a $0.5 \mathrm{M} \mathrm{NaOH}$ solution [162]. For this $\sim 100 \mathrm{mg}$ plant material is extracted in $0.5 \mathrm{M} \mathrm{NaOH}$ solution for $5 \mathrm{~h}$ at $85^{\circ} \mathrm{C}$, afterward filtered $(0.45 \mu \mathrm{m})$ and analyzed.

A more complex method is using hydrofluoric acid (HF), which can be seen not only as extraction but as real digestion. Puppe et al. [166] performed a 2-step extraction method using a closed vessel microwave system. For this, they used $100 \mathrm{mg}$ plant material together with a mixture of $4 \mathrm{~mL}$ distilled water, $5 \mathrm{~mL}$ nitric acid $(65 \%)$ and $1 \mathrm{~mL}$ hydrofluoric acid $(40 \%)$ at $190{ }^{\circ} \mathrm{C}$ for the first step. In the second step, the hydrofluoric acid is neutralized by $10 \mathrm{~mL}$ a $4 \%$ boric acid solution at $150{ }^{\circ} \mathrm{C}$ and can be analyzed afterward.

Another method used for Si extraction from plant material is the lithium metaborate fusion method $[167,168]$. For this, the plant material in the porcelain crucible is ashed in a muffle furnace by gradually increasing temperature to $500{ }^{\circ} \mathrm{C}$ and holding $500{ }^{\circ} \mathrm{C}$ for at least $1 \mathrm{~h}$. Afterward, $5-100 \mathrm{mg}$ of the ash are mixed with lithium meta-tetraborate $\left(1.6 \mathrm{~g} \mathrm{LiBO}_{2}\right.$ and $0.4 \mathrm{~g} \mathrm{Li}_{2} \mathrm{~B}_{4} \mathrm{O}_{7}$ ) is used to extract the $\mathrm{Si}$ at $1000{ }^{\circ} \mathrm{C}$ for $5 \mathrm{~min}$ in the muffle furnace. The obtained bead is transferred into a $10 \%$ nitric acid in a conical flask and stirred at $90{ }^{\circ} \mathrm{C}$ until the bead is dissolved. Afterward, the solution is diluted to $100 \mathrm{~mL}$ with $10 \%$ nitric acid.

Another method to extract plant $\mathrm{Si}$ is the tiron method [169], which is comparable with the $\mathrm{Na}_{2} \mathrm{CO}_{3}$ and the $\mathrm{NaOH}$ method as the sample is also extracted at $85^{\circ} \mathrm{C}$. For this method, $\sim 50 \mathrm{mg}$ plant material was added to $30 \mathrm{~mL}$ of a $0.1 \mathrm{M}$ tiron solution buffered at $\mathrm{pH} 10.5$ and put for $2 \mathrm{~h}$ at $85^{\circ} \mathrm{C}$. For this $30 \mathrm{~mL}$, only $10 \mathrm{~mL}$ are taken and mixed with $10 \mathrm{~mL}$ of $30 \% \mathrm{H}_{2} \mathrm{O}_{2}$ and put again for $1 \mathrm{~h}$ at $85{ }^{\circ} \mathrm{C}$ in order to destroy the tiron, afterward filtered $(0.2 \mu \mathrm{m})$ and analyzed.

Another simple method is the Si analysis by X-ray fluorescence spectrometry [170], for which no extraction is required, but the Si content in $~ 100 \mathrm{mg}$ plant material is directly measured, but calibrations are required. Nakamura et al. [168] compared the $\mathrm{Na}_{2} \mathrm{CO}_{3}$ method with the borate fusion method and found that the $\mathrm{Na}_{2} \mathrm{CO}_{3}$ method resulted in lower Si concentration than the borate fusion method. However, the difference can be $\mathrm{Na}_{2} \mathrm{CO}_{3}$ data can be corrected by a simple equation.

\subsection{Types of Variability}

As discussed above, the division of plant species into active Si accumulators, passive accumulators and excluders is not straightforward, and the same follows for dividing taxa into high- and low-Si accumulators. First, a clear Si content threshold does not exist, although an often-cited and widely accepted threshold is $1 \%$ Si by dry weight or 1000 phytoliths per g dry weight [23]. Second, although the variability of Si content has a clear taxonomic signal, with orders accounting for $67 \%$ of the variation [172], phylogenetic analyses indicate great variations below the order level [23]. For example, most literature 
cites the grass family Poaceae and more generally the order Poales as being the most Si-rich, at least among angiosperms [18,172-174], which is in part why a large portion of plant Si research focuses on this family $[5,18]$. However, Poales is also the only commelinid order to date in which Si-poor families were observed (e.g., Typhaceae) [23]. In contrast, non-commelinid monocots are generally Si-poor $[23,173,174]$, with some exceptions like the orchid subfamily Epidendroideae [175]. The occurrence of high Si contents in a single subfamily of orchids (one of the largest plant families globally) is not unique: 29 of the 412 angiosperm families include both Si-rich and Si-poor species (7\% of all angiosperm families, but $17 \%$ of families for which data exist) [23]. Finally, it should be noted that although most research revolves around seed plants, silicon and phytoliths are common and abundant in many bryophytes and pteridophytes [122,172,176-178] (phytolith-like "mycoliths" also occur in fungi [179]), sometimes in contents that surpass those found in Poaceae species [172].

After its uptake by the roots, monosilicic acid is transported up to the shoot via the xylem, with the transpiration stream acting as the main motive force $[11,16,106,135]$. Within the plant tissues, large quantities of monosilicic acid begin to polymerize, first into polysilicic acid and further into ASi [180-183]. Some organic molecules, such as amines, amino acids and prolines, have been shown to be involved in this process [180-182,184-186]. There are many forms of ASi in plants [183,187] (Figure 2), most notably the cuticle-Si double-layer $[41,53,188]$, cell wall-bound Si [185,189-194], and phytoliths that develop inside cells [63,68-70,173,174,195]. It is unclear whether some of these forms are deposited earlier or at higher rates than others, but variations in their condensation states suggest different formation processes or rates and probably different functions [196]. Some scholars use the term "phytoliths" in a narrow sense to describe ASi formed in short epidermal cells (sometimes called "silica cells" or "raised platforms") and trichomes, while others use it in a broader sense to describe any type of plant ASi formed in direct association to the cell, including long epidermal cells (whose phytoliths are often articulated into "silica skeletons" [133]), trachea, etc. [174,197]. Here, we shall use the broader meaning of the term and specify any particular phytolith subtype when appropriate.

The distribution of $\mathrm{Si}$ among these forms is variable and disputed. While early accounts suggest ASi (mainly phytoliths) constitutes $90 \%$ of plant $\mathrm{Si}[58,198]$, more recent analyses have suggested that ASi constitutes $15-79 \%$ of plant $\mathrm{Si}$, the remainder being mostly polysilicic acid [199]. Despite several decades of studying Si deposition mechanisms, we still have a very partial picture of the topic, focusing on grass species and mostly on their prominent and diagnostic epidermal silica short cells. Blackman proposed one of the earliest developmental frameworks for Si deposition in grasses, which consisted of two main observations, which have been further corroborated by later studies. First, $\mathrm{Si}$ deposition does not take place in all cell and tissue types at the same timings and rates. "Typical" silicification of specialized cells (e.g., short epidermal cells) is constitutive and occurs under all growth conditions and precedes facultative "atypical" silicification of adjacent unspecialized cells (e.g., epidermal long cells and stomatal cells), which possibly depends on sufficient amounts of water, Si and transpiration [63,68,200,201]. Second, some cells (mainly epidermal short cells) undergo differentiation to become specialized Si-accumulating cells and then undergo further anatomical and physiological changes (e.g., lignification and apoptosis) to accommodate Si deposition and filling [69,191,195,202,203]. Later studies have shown that $\mathrm{Si}$ deposition first takes place in the cell wall or other external parts of the cell, and Si filling of the cell lumen takes place only later [191,202,204]. 

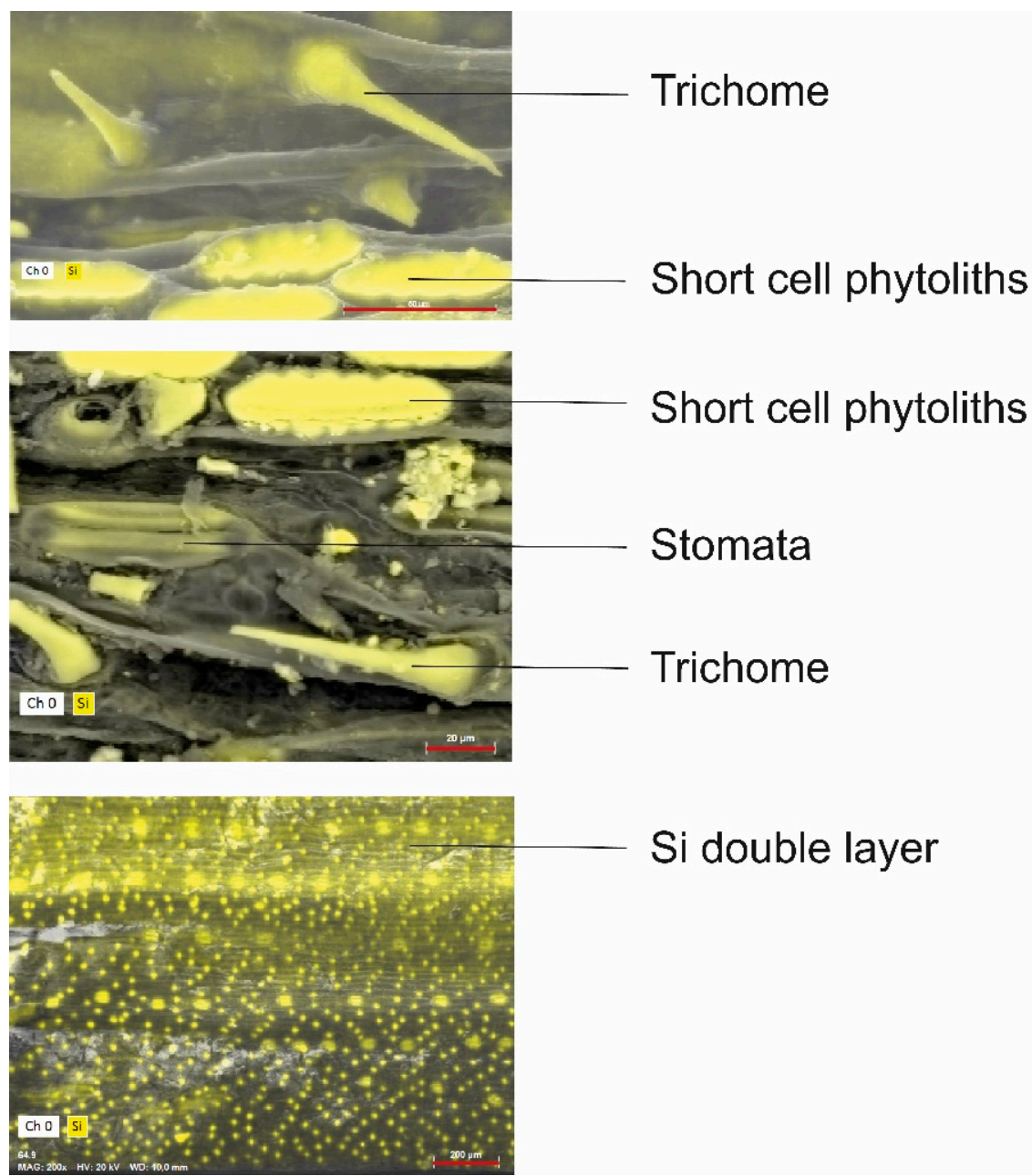

Figure 2. Different Si deposits occurring in the leaves of grasses. Here SEM-EDX pictures of wheat left at maturity. The red line indicates the scale for the different pictures ( $50 \mu \mathrm{m}$ top, $20 \mu \mathrm{m}$ middle and $200 \mu \mathrm{m}$ bottom picture). The SEM-EDX analysis results were provided by J. Busse (ZALF, Germany).

Silicon contents also vary among plant parts. Most evidence suggests that epidermal tissues are the most $\mathrm{Si}$ - and phytolith-rich and thus that plant parts with large surface areas (namely leaves and inflorescences) are more $\mathrm{Si}$ - and phytolith-rich than other parts like stems and roots [59,60,174,205-211]. However, this is not always the case. For once, while most evidence comes from grasses, other herbaceous and woody species present different patterns. In some woody species, phytolith (which are commonly the most abundant $\mathrm{Si}$ form in plants $[58,198,199]$ ) occur in larger amounts in wood and bark than in leaves [174] (but see [209]), and in the forbs stem, Si contents also exceed those in leaves [205,212]. Inflorescences commonly have more $\mathrm{Si}$ than leaves or other vegetative parts in grasses [59,60,137,210,213], but this is not always the case in some grasses [208-210] or in forbs [137]. Many studies have also shown that $\mathrm{Si}$ content in roots is lower than in aboveground plant parts [60,174], but again with some mixed observations [214]. Understanding the sources of differences among plant parts and how these patterns vary among plant taxa may prove to be a complex task. Epidermal tissues are more Si-rich because they are terminal points of the transpiration stream and hence preferable sites for $\mathrm{Si}$ deposition, but many plants actively direct $\mathrm{Si}$ deposition into these tissues and plant parts $[69,191,195,202]$, and this deposited Si plays certain roles that are related to its position (see Section 5.2 below).

These three types of variability (among taxa, among forms and among plant parts) are further manifested-albeit in somewhat different manners-in the variability of phytolith morphologies and morphological groups (morphotypes). This variability is by far the one that is best documented and analyzed [197,215-219], in part because of its usefulness in 
palaeoecology and archaeology [131-133,174,208-210,216,220-230]. Of no less importance, but less developed is the potential of using morphotypical analyses in studying plant evolutionary history, owing to the correspondence of some morphotypes to phylogeny and thus the ability to identify plant taxa ancestors using putative ancestral morphotypes [176,195,231-233].

\subsection{Form, Location and Function}

Despite all the amounts of data and knowledge of the variability of Si in plants, it appears that this knowledge tends to be patchy. This should come as no surprise since the many studies over the years had different questions and purposes. However, this leaves us with a big question: is there a pattern connecting form, location and function? We are capable of partially answering this question since we do know, for example, that Si-rich grasses accumulate Si mostly as phytoliths in aboveground epidermal tissues, which probably plays certain functions. Nevertheless, while evidence for each type of variability is relatively ample, there is only meager evidence for their coalescence into clear patterns (syndromes) that have clear physiological, developmental or ecological implications. If such syndromes exist, then different $\mathrm{Si}$ forms in different plant parts probably have different functions in different taxa and thus reflect physiological and developmental pathways that further have ecological and evolutionary implications $[1,18,234,235]$. For example, do taxa with different $\mathrm{Si}$ forms or that accumulate $\mathrm{Si}$ in different parts, or tissues do this because they have different Si uptake and allocation mechanisms? Do some forms occur earlier, more often or in larger quantities in some plant parts or tissues than others do and is this driven by any internal or external factor? If different syndromes are found in different taxa (or, not less interestingly, if not), what can we learn from it about the evolution of this phenomenon or the mechanisms that govern it? Furthermore, connecting to the Si functions in plants and its soil chemistry, what can we learn from this about the role of $\mathrm{Si}$ in shaping ecosystems and about ecosystem management, or even about shaping and managing the ecosphere as a whole?

Silicon protects plants from drought stress through many mechanisms $[128,236,237]$ (Figure 3), known mainly from grasses. Many of these mechanisms are also relevant for salinity stress alleviation, owing to the multiple similarities between the two stresses [236-239], but we shall focus on drought hereafter. Silicon promotes root growth and improves water uptake by root, allowing plants to maintain stomatal conductance [128,236,240]. While the mechanism and the form of $\mathrm{Si}$ involved in this are not fully understood, it is probable that $\mathrm{Si}$ deposition in the endodermal cell wall is at least partially involved in improving water uptake [241]. Silicon in the cell wall is also involved in regulating stomatal movement and conductance, hence regulating water loss through stomata [193,242-244]. The sub-cuticular Si layer, which has long been suggested to play a role in water loss reduction $[198,245]$, was recently found to reduce water loss from the cuticle by as much as 23\% [246] (but see [242], who found no effect on water loss from the cuticle). Although most leaf surface water loss takes place through stomata [247], this $23 \%$ reduction can be significant. Silicon-most probably in a soluble form-activates several internal physiological mechanisms that signal and alleviate oxidative damages caused by drought, including increasing photosynthesis rates [248-253]. The idea that epidermal phytoliths act as prisms that harvest more light into the mesophyll has little support [254]. Finally, ASi in the soil has been shown to improve water holding capacity and thus water availability to plants $[73,88,101,103]$, possibly due to its hygroscopic properties [102]. Albeit not an in planta process, plants play a key role in the Si cycle and large quantities of soil ASi come from plant litter or herbivore feces [21-23,171,255-265], so this is plants' contribution to their offspring and neighbors, and hence an indirect function through soil appropriation, facilitation and possibly even ecosystem engineering (see Section 6). 


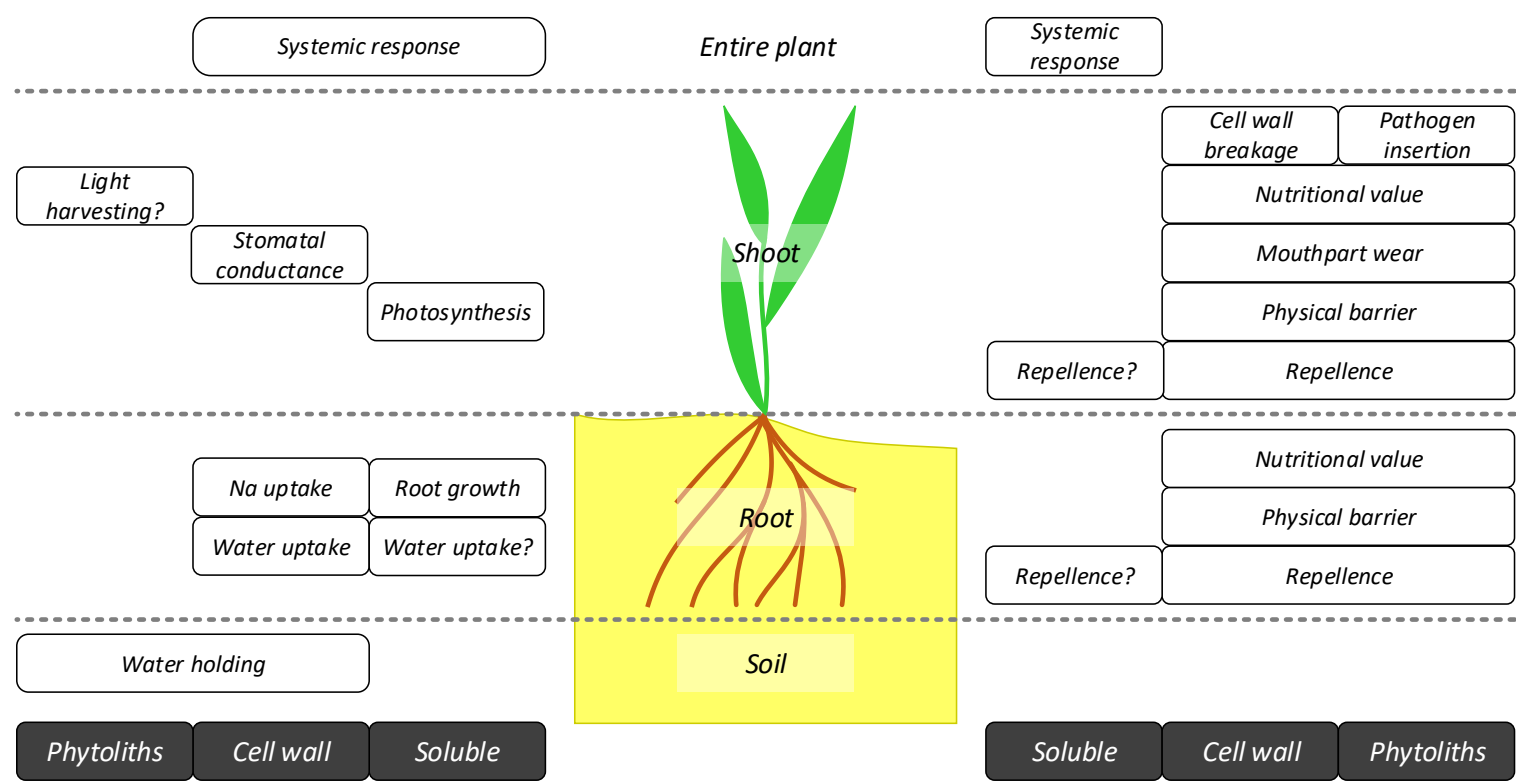

Figure 3. Form, location and function of $\mathrm{Si}$ in plant protection from drought and salinity (left) and from pathogens, fungi and herbivores (right).

The function of $\mathrm{Si}$ in protecting plants from pathogens, fungi and herbivores (Figure 3) includes protection in various stages, from repellence to penetration prevention, to damage to herbivore performance during and post-ingestion, and finally to activation of physiological responses to damage. The type and magnitude of this protection vary among herbivores, depending on their size, feeding guild and Si forms to which they are exposed [235,266]. A repellence function is manifested mainly in studies of invertebrate and vertebrate herbivores, which often prefer Si-poor over Si-rich plant food [140,144,149,267-269] (for a parallel role in sponges, see [270]). It is likely to include both physical repellence by silicified trichomes and short epidermal cells (Figure 2) that increase leaf surface roughness [271], but other mechanisms may also be involved. If repellence does not occur or is not sufficiently effective, Si can prevent pathogens and fungi from penetrating the plant body. This function is fulfilled by ASi (both as epidermal cell phytoliths and within the cell wall) [271-277]. However, there is no empirical evidence for a similar function of the Si-cuticle double layer, contrary to some suggestions $[278,279]$. Comparably, abrasive ASi can damage invertebrate $[267,280,281]$ and vertebrate $[282,283]$ herbivores' mouthparts (but see a critique of tooth wear by phytoliths in $[284,285])$. Furthermore, it is possible sharp phytoliths (e.g., trichomes, Figure 2) may also insert pathogens into herbivores' soft tissues [286]. However, it is unknown at what stage of their development these ASi deposits become sufficiently condensed/rigid to affect herbivores and whether different degrees of condensation/rigidity function differently [196]. While ASi abrasiveness can have a negative effect on herbivores, this effect is probably long-term [280] and does not have an immediate negative effect on herbivores. Nevertheless, once ingested, large quantities of ASi can impair herbivore nutrition through two separate mechanisms. Quantitatively, large ASi contents in food come at the expense of other nutritional components and can even modify plant chemical composition [85,207,287-289]. Qualitatively, cell wall ASi hinders cell wall breakdown in animal intestines, reducing the released amount of chlorophyll and other nutritious compounds that can be digested by herbivores [290]. These two mechanisms, with the addition of low preference to Si-rich plant foods, often results in reduced herbivore growth $[140,146,267,272,280,282,288]$ and even cause a herbivore population decline $[157,159,161]$. There is even some evidence that plant Si can cause urolithiasis [58,291-293] and be carcinogenic [294]. Finally, Si-most probably mainly in its soluble forms, induces several systemic defense mechanisms [147,295-300] (but see [301]), including attracting the herbivore's natural enemies [145]. Notably, apart from a handful of studies 
dedicated to roots [140,147], all other studies focused on plant aboveground parts (mostly leaves) or on systemic responses that also tend to use information from aboveground parts.

The multiple physical, chemical and physiological Si plays in plant life in its various forms (Figure 1), and the benefits they appear to confer on plants, have arisen an intriguing question in recent years: is $\mathrm{Si}$ a partial substitute for carbon [1,2]. The credit for first suggesting this idea goes to Raven, who in 1983 estimated the metabolic costs of Si-based mechanical support are10-20 times less than the metabolic costs of lignin [11]. Several later studies have shown that plant $\mathrm{Si}$ content trades off with plant lignin and cellulose [302,303], phenols [7,207,304-307], and some nutrients' [207,287,289,307] contents. Moreover, grasses accumulate less $\mathrm{Si}$ at higher atmospheric $\mathrm{CO}_{2}$ levels [141,306,308]. However, no such effects of atmospheric $\mathrm{CO}_{2}$ were found in sugarcane [140] and Si-rich trees [309]. There is also no consistent difference in Si content between $C_{3}$ and $C_{4}$ grasses [310], which differ in their carbon use efficiency. Therefore, and also considering the lack of global-scale analysis, the case for a universal tradeoff remains disputed at this point [1].

\section{Implications for Ecosystem Structure, Functioning and Services}

Although the many functions Si plays in plant biology and ecology have been recognized for many years, it is only within the past decade and a half that this understanding culminated in recognition of plant Si uptake as an important phenomenon in ecosystems and as a plant functional trait $[1,2,25,311]$.

\subsection{Effects on Soil \\ 6.1.1. Si Cycling in Undisturbed and Disturbed Plant-Soil Systems}

Mineral weathering represents the ultimate source of $\mathrm{Si}$ in terrestrial ecosystems and thus controls Si concentrations in soils. Weathering in soil-plant systems, in turn, is controlled by climate (precipitation, temperature), specific soil conditions (e.g., mineral composition, quantity and physicochemical properties of amorphous biogenic silica, soil $\mathrm{pH}$ ), and vegetation (Si uptake and recycling) [312-314] (Figure 4). In general, dissolution of minerals is much slower than the dissolution of amorphous (biogenic) silica like phytoliths, i.e., phytoliths are $10^{2}$ to $10^{4}$ times more reactive than clay minerals and primary silicates under common soil pH (about 4 to 8) [315,316]. Consequently, the (re)-cycling of Si by organisms, especially plants, has gained much attention as it strongly influences the $\mathrm{Si}$ cycle on a global scale, especially by accelerating Si turnover rates and export to riverine and marine systems $[259,317]$.

Bioavailable $\mathrm{Si}$ is accumulated to a large extent in several major biome types, e.g., forests $\left(11.7 \mathrm{Tmol} \mathrm{y}^{-1}\right)$, steppes $\left(13.3 \mathrm{Tmol} \mathrm{y}^{-1}\right)$, and cultivated lands $\left(29.4 \mathrm{Tmol} \mathrm{y}^{-1}\right)$ out of a total of $84 \mathrm{Tmol} \mathrm{y}^{-1}$ for all terrestrial biomes [21,256]. However, humans directly affect the distribution and size of these biomes and thus influence corresponding $\mathrm{Si}$ cycling through intensified land use, i.e., forestry and agriculture (changes of soil properties and vegetation) [318-320]. Additionally, increased greenhouse gas emissions and consequential changes in climate conditions may have severe impacts on Si cycling [258]. Clymans et al. [321] estimated that the total amorphous (biogenic plus minerogenic) $\mathrm{Si}$ pool in temperate soils decreased by about $10 \%$ within the last 5000 years due to human land use. Amorphous silica, in turn, has been found to increase the water-holding capacity of soils (see Section 3.2 [103]), influence nutrient supply (e.g., phosphorus and organic matter mobility [81,83]) and act as the main source for bioavailable Si [166,322].

Concentrations of amorphous $\mathrm{Si}$ are considerably lower in agricultural soils than nonagricultural soils, e.g., forest or steppe soils. This is because $\mathrm{Si}$ exports through harvested crops generally lead to loss of $\mathrm{Si}$ in agricultural plant-soil systems (i.e., anthropogenic desilication) [20,323-326]. However, some agricultural practices might also increase Si availability in soils, e.g., human set fires [327], the application of Si-rich fertilizers [26], or liming ( $\mathrm{pH}$ effect, [328]). On a global scale, about $35 \%$ of $\mathrm{Si}$ accumulated in vegetation is synthesized by field crops, and this proportion is going to increase with increased agricultural production within the next decades [256]. Si uptakes, which can be assumed to equal Si outputs 
by harvesting, of cereal crops are quite high and reach up to several $100 \mathrm{~kg}$ per hectare in a year (e.g., rice: $270-500 \mathrm{~kg} \mathrm{Si} \mathrm{ha}^{-1} \mathrm{y}^{-1}$ [20]; 230-470 $\mathrm{kg} \mathrm{Si} \mathrm{ha}^{-1} \mathrm{y}^{-1}$ [329]; sugarcane: $379 \mathrm{~kg} \mathrm{Si} \mathrm{ha}{ }^{-1} \mathrm{y}^{-1}$ [330]; wheat in the temperate zone: $20-113 \mathrm{~kg} \mathrm{Si} \mathrm{ha}^{-1} \mathrm{y}^{-1}$ [20]).

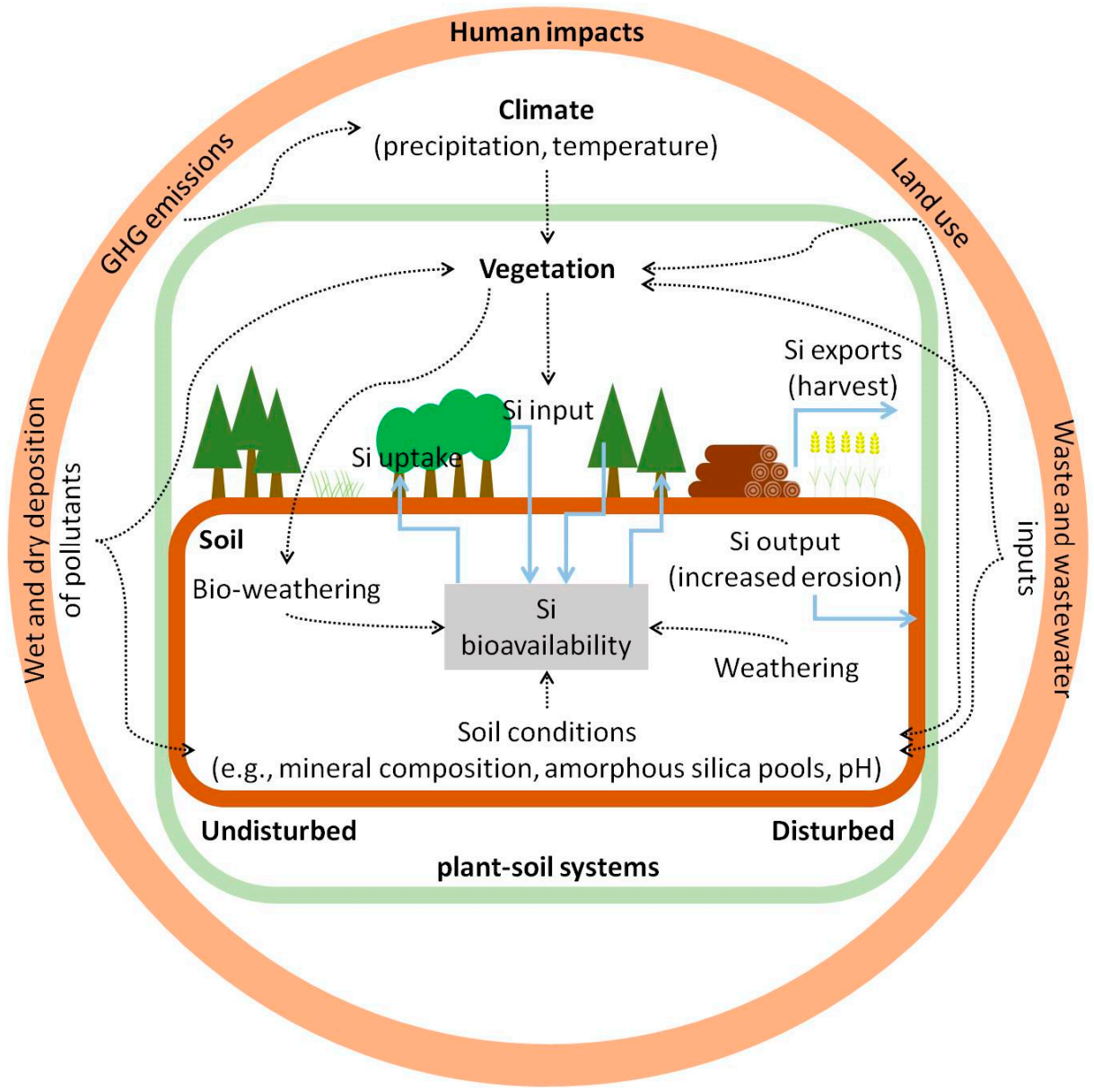

Figure 4. Schematic overview of Si cycling in undisturbed (unused, natural) and disturbed (used) plant-soil systems. Si bioavailability in soils, and thus Si cycling, is strongly influenced by human impacts, i.e., greenhouse gas (GHG) emissions, land use (agriculture, forestry), pollution via wet and dry deposition, and waste and wastewater inputs.

In contrast to natural ecosystems (Si uptake of 2-127 $\mathrm{kg} \mathrm{Si} \mathrm{ha}^{-1} \mathrm{y}^{-1}$ [20]), where large amounts of $\mathrm{Si}$ are recycled year by year [322], the annual Si exports in agricultural soil-plant systems are mostly not compensated. However, targeted manipulation of $\mathrm{Si}$ cycling (e.g., Si fertilization, straw recycling) might be a promising strategy to both prevent desilication of agricultural plant-soil systems and consequently improve crop resistance against abiotic and biotic stress (see Section 5.3), and enhance carbon sequestration in agricultural biogeosystems to mitigate climate change [331-333]. Carbon sequestration in agricultural systems may be enhanced by the regulation of weathering (e.g., silicate rock powder amendment), organic $C$ stabilization (e.g., silicon and biochar fertilization), and phytolith-occluded carbon (e.g., partial straw retention after harvest) [333] (Figure 4). However, it should be noted that the potential of phytoliths in $C$ sequestration is still under controversial discussion (see the review by Hodson [334] and references therein). However, this carbon occlusion is potentially the carbon remaining from the protein template shaping the phytoliths [184].

Guntzer et al. [324] analyzed archived soil and plant samples of the long-term Broadbalk Winter Wheat Experiment at Rothamsted Research in the UK. They found that the long-term removal of wheat straw considerably decreased amorphous silica pools in soils. 
However, they did not observe a distinct relationship between the decrease of amorphous silica and a corresponding decrease in Si concentrations of crop straw. In fact, Guntzer and colleagues [324] found such a relationship only for the samples taken before the year 1944. After this year, Si concentrations in straw tended to increase. From their results, Guntzer et al. [324] concluded an increased soil $\mathrm{pH}$ due to periodic liming to increase amorphous silica (i.e., phytoliths) dissolution, and thus to represent the main driver of increased Si uptake by the cultivated wheat plants. This is underpinned by a recent study of Caubet et al. [335], who ascribed an increase of calcium chloride extractable Si in cultivated soils (perennial and annual crops) in France to liming. However, it must be kept in mind that $\mathrm{Si}$ availability in (agricultural) soils is determined by a complex interaction of factors, and thus liming effects on Si availability follow no general rule, i.e., there are studies showing negative and other studies reporting positive correlations between $\mathrm{pH}$ and Si availability (see the review by Haynes [328]).

A long-term field experiment (established in 1963) in NE Germany revealed that about $43-60 \%$ of Si exports could be saved by crop straw recycling [336]. These authors found crop straw recycling to become more effective the longer straw recycling is applied, indicated by an increase (or replenishment) of plant-available $\mathrm{Si}$ in soils with time, which was also reflected by increasing phytolith contents in these soils. In fact, plant-available $\mathrm{Si}$ increased from about $5 \mathrm{mg} \mathrm{kg}^{-1}$ (a value that is comparable to other agricultural sites in the temperate zone [337]) to about $10 \mathrm{mg} \mathrm{kg}^{-1}$ (comparable to undisturbed ecosystems like forests under temperate conditions, e.g., $10-40 \mathrm{mg} \mathrm{kg}^{-1}$ [338]; $7-40 \mathrm{mg} \mathrm{kg}^{-1}$, [339]; $4-80 \mathrm{mg} \mathrm{kg}^{-1}$ [337]) within 42 years of straw recycling [336]. Thus, straw recycling in combination with soil [340] and foliar [341] Si fertilization might be the most promising strategy to restore natural $\mathrm{Si}$ recycling processes in agricultural ecosystems to the highest possible extent and produce resilient crops in modern, sustainable agriculture.

Klotzbücher et al. [342] analyzed Si mobility in soils depending on sorption competition with highly competitive compounds (i.e., dissolved organic matter and phosphates). From their results, they concluded a weaker binding strength of $\mathrm{Si}$ (as compared to $\mathrm{P}$ and dissolved organic matter) to Fe oxides leading to Si mobilization by the input of $\mathrm{P}$ and dissolved organic matter. However, it should be kept in mind that the laboratory experiments of Klotzbücher et al. [342] were performed under acidic conditions ( $\mathrm{pH} 4$ ), resulting in a potentially decreased binding strength of $\mathrm{Si}$ due to slowed polymerization of $\mathrm{H}_{4} \mathrm{SiO}_{4}$ [26]. According to these findings, it can be assumed that mineral fertilization, as well as organic matter input by crop straw recycling, should increase Si mobilization in soils resulting in potentially higher $\mathrm{Si}$ accumulation in plant biomass [20]. Li et al. [343], for example, found combined Si-P fertilizers to increase concentrations of plant-available $\mathrm{Si}$ in soils leading to higher biomasses and phytolith contents of rice plants. However, because Si-P interactions in the soil-plant system are driven by complex biogeochemical processes that are still not fully understood [83], further studies are needed to shed light on this aspect. In this context, it is of great interest to study to what degree Si uptake of cultured plants is determined by their phylogenetic position and environmental factors like temperature or Si availability [172,173,304].

Miles et al. [344] analyzed 28 sites located throughout the sugarcane-growing areas of South Africa and found a close correlation between plant-available Si in soils and Si contents in sugarcane leaves. Regarding rice production, Korndörfer et al. [345] analyzed 28 field experiments in the Everglades Agriculture Area, representing a wide range of available $\mathrm{Si}$ in soils. They found plant-available $\mathrm{Si}$ in these soils to be correlated with $\mathrm{Si}$ contents in rice straw. In contrast to these studies, which considered several study sites with relatively large gradients in plant-available $\mathrm{Si}$, Klotzbücher et al. [303] found no relationship between plant-available $\mathrm{Si}$ in soils (herein concentration of dissolved $\mathrm{Si}$ in soil solution) and $\mathrm{Si}$ contents in rice straw in one (i.e., the drier one) of two analyzed cropping seasons in a field experiment in Southern Vietnam. However, they found such a correlation in the second cropping season, i.e., the wetter one. From their results, Klotzbücher et al. [303] speculated climatic differences to be responsible for their observation (cf. [346]) and concluded field 
experiments to be inconsistent with results from laboratory studies regarding relationships between plant-available $\mathrm{Si}$ in soils and Si uptake by plants (e.g., [347,348]). This is underpinned by a study by Keeping [349], who found that the uptake of Si by sugarcane in a shade house pot experiment did neither reflect the concentration of plant-available $\mathrm{Si}$ in soils nor the Si content of used Si sources (calcium silicate slag, fused magnesium (thermo) phosphate, volcanic rock dust, magnesium silicate, and granular potassium silicate).

Non-agricultural soils like forest soils are characterized by a soil horizon-related distribution of amorphous silica showing the highest concentrations in the organic horizons (dominated by phytogenic silica) and a decrease in the deeper mineral horizons [322,337,350]. However, bioturbation and percolation can affect the distribution of amorphous silica [171,339,351,352]. The concentration of phytogenic silica in forest soils mainly depends on the quantity of plant materials, i.e., litterfall and other plant residues supplied to soils (phytolith input) and the loss of phytoliths (phytolith output) via harvesting of trees, erosion (wind, water), translocation (bioturbation, percolation), and dissolution (e.g., [22,258,312,313,353]). In this context, it should be kept in mind that phytolith inputs are not only driven by aboveground plant materials but also by plant roots [354,355]. Physicochemical properties of phytogenic silica (phytoliths) control their susceptibility to dissolution, and these properties differ between fresh and aged phytoliths with implications for $\mathrm{Si}$ availability in soils [356]. Changes of the dominating vegetation by humans (deforestation) are leading to large $\mathrm{Si}$ exports declining the concentration of amorphous Si in soils [318]. Moreover, increased erosion [318] or human-set fires [327] have the potential to alter amorphous silica concentrations in soils, and thus Si availability. The depletion of pedogenic Si pools in the long-term, i.e., during ecosystem retrogression, might even increase the importance of Si recycling by plants [357]. Finally, plants themselves can actively increase Si bioavailability in soils by increasing soil weathering in the rhizosphere (bio-weathering, see [358-360].

\subsubsection{Concluding Remarks}

Regarding biogenic amorphous $\mathrm{Si}$ in soils, it should be kept in mind that the vast majority of studies have been focused on phytogenic silica, i.e., phytoliths (cf. [26]). However, the importance of other biogenic Si pools, especially the protozoic one (represented by a group of protists, i.e., testate amoebae), for $\mathrm{Si}$ cycling in some ecosystems has been revealed, and their significance for Si cycling in terrestrial ecosystems might be comparable to the role of protists (i.e., marine diatoms) for $\mathrm{Si}$ cycling in the oceans (see the review by Puppe [361]). Recent studies indicate that protozoic Si pools are strongly affected by land use [362,363], but we still do not know which effects protozoic Si pool changes have on the ecosystem scale (e.g., impacts on Si availability). Furthermore, we still do not know if these organisms are able to increase weathering rates in soils by bio-weathering. In fact, there are some hints that bio-weathering may play a role in protists [364], underpinning their potential significance for $\mathrm{Si}$ cycling in terrestrial ecosystems.

The bioavailability of Si in soils is controlled by at least three key factors: (i) the Si concentration in soil solution, (ii) the reserve in the solid phase as Si source (minerogenic/pedogenic, biogenic, adsorbed, or fertilizer $\mathrm{Si}$ ), and (iii) the $\mathrm{Si}$ adsorption capacity or retention capability of the soil $[328,365]$. As all of these factors are the result of complex biogeochemical interactions and thus differ from one soil to another, a general understanding of $\mathrm{Si}$ availability in different soils and its uptake by plants and other organisms represents a hard-set challenge. Unfortunately, there is no standard extraction method for the determination of Si availability in soils yet (see [26] for more details), and thus different studies often show inconsistent results. Crusciol et al. [366] showed that correlations between plant-available $\mathrm{Si}$ in soils and $\mathrm{Si}$ concentrations in sugarcane were not only dependent on soil texture but also on the used extractant (i.e., $\mathrm{CaCl}_{2}$, deionized water, $\mathrm{KCl}$, sodium acetate buffer at $\mathrm{pH} 4.0$, and acetic acid). In fact, there is no common standard procedure for the evaluation of plant-available $\mathrm{Si}$ in soils because these procedures have been developed for specific plants in specific climates, i.e., mainly sugarcane and rice in (sub)tropical zones (cf. [72]). 
What we need now is detailed research on methods for a reliable determination of Si availability in soils of undisturbed (natural) and disturbed (used) plant-soil systems (Figure 4). In this context, a combination of (i) different information on the Si status of soils (e.g., the concentration of extractable plant-available Si, quantity and quality of solid biogenic and pedogenic Si phases, retention of plant-available Si in soils, the influence of climate and vegetation) and (ii) laboratory and (long-term) field experiments (e.g., identifying of drivers of plant-available Si in different soils, balances of Si cycling in plantsoil systems) may be the most promising approach to enlighten the complex interactions in biogeochemical Si cycling. Such knowledge is crucial for the understanding of ecosystem structure, functioning, and services.

\subsection{Effects on Species Interactions, Community Structure and Net Primary Productivity}

Due to the multiple functions Si has for plants and the benefits it confers on them, it is only natural to conclude that it has implications on plant fitness, interspecific plant-plant and plant-animal interactions, and hence also on ecosystem structure and functioning [1,2,24,25]. While there is increasing evidence for some of these implications and for the overall large-scale story-as we describe here- - the mechanisms and phenomena are often not well understood and sometimes disputed. For a start, clear evidence for the effect of Si on plant fitness (i.e., reproductive success and its contribution to the next-generation) come mainly from grain/seed yield measurements carried out in agricultural studies, which aim to assess Si's contribution to crop production (e.g., [10,85,253,367-372]). Apart from focusing on crops rather than on a broader range of plant species, the application of these measurements for ecological fitness assessment requires information about seed germination and seedling survival. Moreover, for understanding the effects of Si on plant-plant interactions (namely, competition), let alone on plant community composition and its dynamics, a species' fitness needs to be converted into relative fitness (i.e., relative to neighboring species). Evidence for $\mathrm{Si}$ affecting interspecific competition is meager from a single study of competition between two grass species [152]. Understanding how Si affects interspecific competition can be useful for crop growing, especially if the benefits of Si to a crop are smaller than its benefits to competing weeds.

By far, the most intensively studied effects of Si on plant interactions are those that focus on plant-herbivore interactions. We have already discussed the effects of plant Si uptake and accumulation on herbivores (see Section 5 above and Figure 3), but no less intriguing are the effects in the opposite directions. Among the early indications for herbivory affecting plant Si content come from field studies in the 1980s, which have shown that grasses that grow near rodent colonies had higher Si contents than those away from the colonies $[150,151,154,156,373,374]$. For once, continuous severe herbivory is likely to select in favor of plants that possess anti-herbivory defenses. In those species and cases where Si accumulation plays an anti-herbivory role, it should be no different [137]. Some studies show that under heavy grazing, grasses possibly prefer habitats with higher soil Si availability $[150,151,374]$, which may suggest selection in favor of more Si-rich habitats under herbivory stress [143]. However, this correspondence may be circumstantial or a result of long-term effects of herbivory on soil Si availability (see Section 6.3 below). Moreover, evidence for the evolution of plant Si accumulation as being driven by herbivory is limited and disputed [23,235,375,376].

A better supported, more immediate effect is the induction of plant Si accumulation by herbivory [143] (evidence for a comparable induction by pathogens and fungi was also observed [275,377]). Several studies have documented the induction of Si accumulation following herbivory in grasses $[144,150,157,159,374]$. Nevertheless, the degree of induction varies among herbivores [134,144,148] and plant genotypes [148,152,160]. A lack of induction in some studies in which defoliation was simulated by clipping suggests that at least part of the variation in effects of different herbivores is connected directly to how the herbivore consumes plant biomass, with saliva possibly being an elicitor $[144,150,151,374]$. However, it is also possible that induction does not occur in some 
laboratory experiments $[144,151,153,154]$ because of insufficiently long exposure periods in controlled experiments [134,144]. Moreover, it is possible that prolonged (millennial-scale) heavy grazing selects in favor of constitutive Si accumulation [137]. Among non-grasses, evidence for such an induction - or at the very least to a variation in Si content related to herbivory intensity-is rare and may be coincidental [134,137]. One important outcome of the reciprocal interaction between plant $\mathrm{Si}$ accumulation and herbivory is a negative feedback loop of herbivore population size and grass Si content, augmented by delayed responses $[157,159,161,378]$. According to this model, increases in herbivore population sizes select for higher plant $\mathrm{Si}$ content, which in turn reduces food quality and causes a decline in herbivore population size, hence removing the selective pressure from the grasses and allowing their Si contents to decline.

The variations among species in plant Si contents and its responses to external variables (e.g., aridity and herbivory) also suggest that plant $\mathrm{Si}$ content affects plant community composition and structure $[1,379]$. To date, there have been no studies that demonstrate such effects directly. However, Plant community composition is clearly associated with $\mathrm{Si}$ and Ca pools and the interaction between them [380]. Moreover, in a long-term plant diversity manipulation experiment, plant Si has been shown to play a role in driving consumer community composition [379]. Schaller and colleagues [381] have proposed a model for plant community composition and biomass production based on soil $\mathrm{Ca} / \mathrm{Si}$ ratios. Moreover, in a broad-scale study, plant Si content was found to have some effect on ecosystem structure, and most prominently on its herbivore component [379]. On a global scale, biomes with higher plant $\mathrm{Si}$ contents tend to have higher net primary productivity (NPP), even when forests and open-habitat biomes are analyzed separately [21]. Concrete evidence for plant Si playing a role in governing community and ecosystem structure, and furthermore ecosystem functioning, do not exist yet, and our understanding of such a role are based almost solely on models and correlations. Nevertheless, the theoretical knowledge points strongly to this direction, stimulating discussions and attention to the issue, so it is probably not long before empirical evidence follows.

\subsection{Effects on Biogeochemical Cycles}

6.3.1. The Ecosystem Scale

The known and expected effects of plant $\mathrm{Si}$ on ecosystem structure and hence on their functioning (e.g., NPP), as manifested on a global scale, suggest that this phenomenon also affects biogeochemical cycles. The obvious of these is the Si cycle. Plants recycle large amounts of Si globally, ranging from 2 to $8 \mathrm{t}$ dissolved $\mathrm{Si} \mathrm{km}{ }^{-2} \mathrm{y}^{-1}$ from grasslands, forests and saltmarshes [255,262]. Much of this $\mathrm{Si}$ is eventually exported to rivers, lakes and oceans [21,25,255,258,382-385]. In a study from Hawaii, for example, Derry et al. [384] estimated that as many as $68-90 \%$ of dissolved $\mathrm{Si}$ in stream water passed through plants. Nevertheless, Si does not affect the Si cycle only but also the carbon, nitrogen and phosphorous cycles. Some of the mechanisms underlying these effects at the smaller scales (e.g., individual plants to ecosystems) are known. We shall focus here on five aspects: effects of Si on plant stoichiometry and litter decomposition, carbon and nitrogen occlusion in plant $\mathrm{Si}$ and phytoliths, Si cycling (with emphasis on the roles of weathering and herbivory), and the possible coupling of the Si and carbon cycles.

As $\mathrm{Si}$ is increasing nutrient availability in soils (e.g., phosphorus and nitrogen) [81], it is not surprising that the nutrient status of plants is also improved due to $\mathrm{Si}[85,386]$. $\mathrm{Si}$ is competing with nutrients for binding sites on soil minerals, and this increases their availability for plant uptake. The same effect is suggested to occur within the plants, with Si potentially increasing nutrient mobility in plants too, and also potentially increasing expression of $\mathrm{P}$ transporter genes [387]. These positive effects of $\mathrm{Si}$ and plant nutrition are not only shown for grasses $[85,207,388]$ but also for legumes with Si increasing N-fixation by rhizobacteria [389]. However, as $\mathrm{N}$ fixation being increased by better P nutrition [5,390] and Si increasing plants' P nutrition (as shown for grasses, see above), the positive effect of $\mathrm{Si}$ on $\mathrm{N}$ fixation may be indirectly due to Si increasing plants P nutrition. For sugarcane, 
no positive effect of Si on P nutrition was found [391]. In contrast, Xu et al. [91] found no positive effect of $\mathrm{Si}$ on $\mathrm{N}$ in legumes. Overall, the positive effect of $\mathrm{Si}$ on plants' $\mathrm{P}$ status seems to be much clearer than the effect of $\mathrm{Si}$ on plants' N status. Another main pattern is the decrease of $C$ concentration with increasing Si concentration in plants, which was suggested as a "carbon partial substitution by Si" in the 1980s by Raven [11]. This pattern of decreasing $\mathrm{C}$ with increasing $\mathrm{Si}$ concentrations in plants was found in numerous studies $[85,207,303,304,388]$. This is, of course, no substitution of $C$ atoms by $\mathrm{Si}$ atoms in terms of function, but more a specific volume of plant tissue that is filled with $\mathrm{Si}$ compounds instead of $C$ compounds.

Due to the changes in plant nutrient status-especially for $\mathrm{C}, \mathrm{N}$ and $\mathrm{P}$ - the relation and stoichiometry between those elements also changed. As $C$ concentration for wheat is decreasing due to $\mathrm{Si}$ accumulation and $\mathrm{P}$ concentration increasing, the resulting number for the $\mathrm{C} / \mathrm{P}$ ratios is lower [85]. At constant $\mathrm{N}$ concentration, by increasing $\mathrm{P}$ concentrations in wheat due to $\mathrm{Si}$, the N/P ratio is also lower [85], although no clear pattern of Si effects on stoichiometry was found in sugarcane [392]. A large study revealed a negative relationship between Si and N/P ratios for wetland and submerged species and a negative relationship between $\mathrm{Si}$ and both $\mathrm{C} / \mathrm{N}$ and C/P ratios for submerged species [289]. A study of the effect of $\mathrm{Si}$ fertilization on sugarcane found an increase in the $\mathrm{C} / \mathrm{N}$ ratio by $\mathrm{Si}$ for different cultivars and a decrease in the $\mathrm{C} / \mathrm{P}$ ratio for one cultivar [391]. A study analyzing grass species in China found an increase in $\mathrm{C} / \mathrm{N}$ ratio with increasing $\mathrm{Si}$ and a decrease in both $\mathrm{C} / \mathrm{P}$ and N/P ratios with increasing Si [393].

With the changes in plant nutrient concentration by $\mathrm{Si}$, an effect on plant litter and organic matter decomposition is possible. It was shown that leaf material from reed $[394,395]$ and rice [348,396] with high Si concentration decomposed faster than a litter of conspecific plants with a lower Si concentration. However, Emsens et al. [397] found no effect of plant material Si concentration on decay rate. Increased respiration of organic matter with increasing Si availability was found for arctic soils [83] and peat [81]. Most recently, it was shown that the effect of Si stimulating respiration of organic matter is only occurring under oxic conditions, whereas under long-term reduced conditions, no effect was found [398]. This effect of $\mathrm{Si}$ increasing soil respiration under oxic conditions may be explained by the fact that $\mathrm{Si}$ increases $\mathrm{P}$ concentrations in soil pore water $[83,398,399]$ and with this the nutrient availability for the microbial decomposer community. Furthermore, it was shown that an increase of $\mathrm{Si}$ in soil pore water might also be able to mobilize carboxylic groups from soil organic matter particles, hence potentially additionally increasing litter decomposition [399]. Another potential explanation for how Si is accelerating organic matter respiration is by a change in soil microbial decomposer community, as shown for reed litter decay - where Si reduced the concentration of ergosterol as a measure of sporulating fungi [395] — and for rice litter-where the abundance of increase in saprotrophic fungi increased with increasing $\mathrm{Si}$ availability [396]. Hence, how $\mathrm{Si}$ is altering the soil microbial decomposer community is currently unclear, as the existing studies partially contradict each other.

\subsubsection{The Global Scale}

Since the formation of phytoliths, especially in "typical" specialized epidermal silica short cells, is a controlled process of cell modification, apoptosis and complete lumen filling $[69,191,195,202-204]$, it often results in the occlusion of carbon- and nitrogen-rich organic remnants of cell components (presumably from the nucleus) within the phytolith $[184,189,333,400-410]$. Some studies indicate that at least some of these carbon- and nitrogen-rich organic compounds do not originate in the host cell but are taken up directly from the soil via the roots (and therefore, are "old carbon" that cannot be used for carbon dating) [409,411-415]. Further analyses of these organic inclusions indicate that they contain amino acids but not DNA, which seems inconsistent with the idea that they originate in the cell nucleus $[410,416]$. This carbon can potentially be preserved within the phytoliths for millennia or more but might be more susceptible to post-depositional oxidation than 
thought [410]. Some scientists argue—-based on theoretical models—that this occlusion has an appreciable impact on carbon sequestration [333,400,401,417-419], but it probably does not account for more than $2 \%$ of the total terrestrial carbon sink $[1,400,420]$.

An important process in the Si biogeochemical cycle is the weathering of silicate minerals. These minerals vary in their dissolution rates and conditions, from the durable slow-weathering primary silicate minerals to the more labile and fast-weathering ASi [76,315,316,421,422] (there are also differences in ASi dissolution according to plant type [421,423]). Plant Si plays an appreciable role in this process by two main mechanisms. First, plant $\mathrm{Si}$ that is reincorporated in the soil through plant litter is a significant soil Si pool, which consists of various Si forms with different physicochemical properties and dissolution dynamics [315,316,322]. For example, the Si double-layer dissolves faster than epidermal silica short cells [395]. Even among phytoliths, some morphotypes are more soluble than others [424-426]. Second, Si uptake by plants imbalances the soil equilibrium of different $\mathrm{Si}$ forms (it removes soluble $\mathrm{Si}$ and reincorporates it into the soil as $\mathrm{ASi}$ ), and thus promotes re-equilibration through silicate mineral weathering [22,171,256,263,359,424], especially if some of the plant $\mathrm{Si}$ is exported by herbivores, farmers, etc., [20,260,422]. It is possible that this process is often accelerated by plant excretion of organic acids that dissolve mineral $\mathrm{Si}$ in order to meet plant $\mathrm{Si}$ demands (cf. [359]).

Herbivores are now acknowledged as being one of the three main agents of nutrient cycling, alongside decomposition and fire [427,428]. Likewise, herbivores that consume large amounts of Si-rich plant biomass (e.g., grazers) play an appreciable role in Si cycling. First, by exerting stress on plants, herbivores may induce Si uptake from the soil [143,144,151], hence increasing plant demand for soluble $\mathrm{Si}$ and thus the weathering of silicate minerals to meet this demand. Second, variations of herbivore feeding preferences and plant resistance to herbivory can alter plant community taxonomic and functional composition [429-432], as seen in several studies that show that grazing increases plant and community Si contents $[150,151,154,156,160,433]$. Therefore, herbivory may be a further catalyst of Si uptake from the soil and of ecosystem-level plant Si demand. Third, plant Si is also affected by ingestion within herbivores' bodies due to chemical conditions-and possibly enzymatic activity - within herbivores' digestive systems [255]. Like the case of dissolution in soils, and likely for the same reasons, phytolith morphotypes vary in dissolution rates [425,434]. Eventually, herbivores excrete these modified Si pools within feces [261], which by itself has chemical properties that affect soil chemistry. The fecal Si pool is more readily available for dissolution and, being in a more aqueous medium on top of the soil, is more susceptible to horizontal translocation and export from the ecosystem, making herbivores important players in Si export to rivers, lakes and oceans [21,25,255,258,382-385]. Finally, unlike plants, herbivores are not mobile but sessile and can, therefore, directly translocate $\mathrm{Si}$ horizontally following their diurnal movement. There are, for instance, several examples for accumulation of phytolith-rich deposits in livestock enclosures and following human secondary use of livestock feces [208,434-441].

In recent years, some scholars have advocated a coupling-or at the very least interaction-between the $\mathrm{Si}$ and carbon cycles, or more generally an effect of plant $\mathrm{Si}$ uptake and accumulation on the carbon cycle $[1,21,303,333,405,417,422,442]$. Several lines of evidence and reasoning - which we have discussed above-have led to this suggestion. One such line of evidence comes from the tradeoffs between plant Si content and some organic plant components, suggesting a Si-carbon tradeoff $[1,7,207,302-307]$. This is further augmented by evidence for plant Si uptake affecting plant stoichiometry and trading off with some nutrients $[193,271,273,290]$. These interactions and putative tradeoffs can act in various and even contrasting manners. On one hand, if $\mathrm{Si}$ can partially replace carbon, then its uptake can theoretically reduce carbon sequestration by plants. On the other hand, Si uptake and accumulation can improve carbon use efficiency and plant nutrition, and thus plant performance, hence having an overall positive effect on carbon sequestration by plants. Indeed, biomes dominated by Si-rich plants tend to be more productive [21]. Another path by which Si can improve ecosystem productivity is its involvement in soil appropriation. For example, soil ASi—of which a large part is of plant origin—improved 
soil water holding capacity and thus can reduce drought stress [103]. By taking up soluble $\mathrm{Si}$ from the soil and reincorporating it into the soil as $\mathrm{ASi}$, plants imbalance soil $\mathrm{Si}$ forms and promote silicate mineral weathering $[22,171,256,263,359,424], \mathrm{a} \mathrm{CO}_{2}$-consuming process $[313,405,422,443]$. Carbon occlusion within phytoliths-despite the controversies about the origin of this carbon [409,411-415]—is another mechanism by which plant Si can affect the carbon cycle $[333,400,401,417-419]$, albeit only minor compared to other forms of plant carbon sequestration $[1,400,420]$.

Silicon's involvement in plant-herbivore interactions can also affect the carbon cycle. On one hand, herbivores accelerate Si cycling, which by extension may accelerate the carbon cycle, for example, by promoting silicate mineral dissolution. On the other hand, Si's role in deterring herbivores or impairing their ability to ingest and digest plant biomass can reduce plant carbon turnover rates. The terrestrial $\mathrm{Si}$ cycle can also affect the marine $\mathrm{Si}$ and carbon cycles since accelerated Si cycling on land can enrich marine systems in Si and thus promote the growth of Si-rich biota (e.g., diatoms) and increase marine NPP [25,255]. Falkowski et al. [444], for example, suggested that the evolution of grasslands (dominated by grasses and grazers, two important Si-cyclers) released large amounts of Si into oceans and facilitated a surge of diatom evolution. Admittedly, some of the effects that Si uptake and cycling by plants has on the carbon cycle are uncertain or minor, but overall they may accumulate into an appreciable effect.

\subsection{Silicon and Ecosystem Services}

The multifunctionality of soil Si and its uptake and cycling by plants, as well as their many benefits for humans, imply that we should consider plant and herbivorous Si cyclers as providers of some ecosystem services (Figure 5). Many of these are supporting services, including soil appropriation and improvement of soil nutrient and water availability to plants [88], and possibly also increasing NPP [21], which is a provider of biomass (i.e., food for wildlife) and a carbon sink. Physically deterring herbivores and sometimes attracting their natural enemies can have secondary protective effects on neighboring plant species that lack these defenses $[429,445,446]$. Silicon cycling may even support evolution: its export to oceans may have contributed to diatom diversification [444], and its increased availability in soils may have contributed to the early diversification of some Si-rich angiosperm clades [23] (see comparable ideas regarding the evolutionary role of resource and nutrient cycling in general: $[233,427,444,447,448])$. Silicon can also provide some regulating services. For example, by promoting plant growth, carbon occlusion in phytoliths and silicate mineral weathering [400,405], as small as any one of these processes may be on its own $[1,400,420]$. Si uptake and accumulation is likely to have some contribution to removing atmospheric $\mathrm{CO}_{2}$ and thus regulating the atmospheric composition and global climate. 


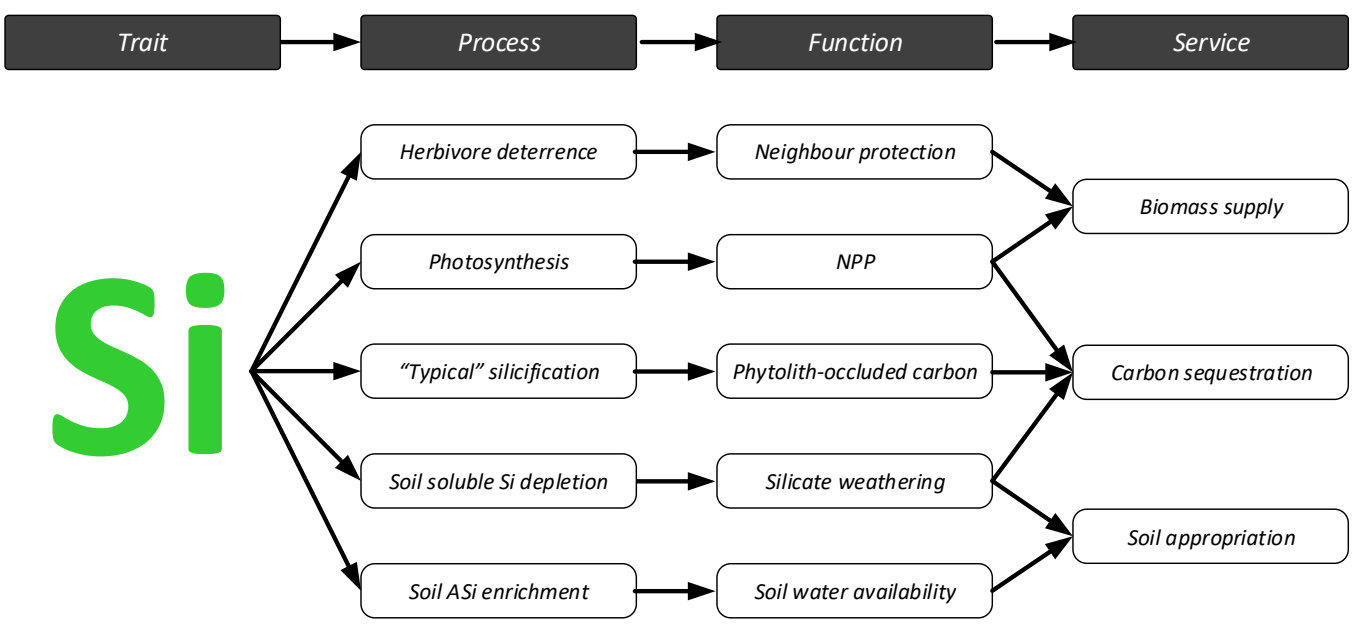

Figure 5. Several examples of how the trait (plant Si uptake and accumulation) drives processes that govern ecosystem functions and how these functions contribute to ecosystem services.

\section{Conclusions}

Many plants (including some prolific families like grasses) can take up Si from the soil, accumulate it within their tissues (where Si plays some biological roles) and then reincorporate it into the soil through litter creates an intricate network of feedback mechanisms in ecosystems. The bidirectional effects of soil properties on plant Si uptake and plant litter on soils suggests a true soil-plant continuum. To these, we should add the effects of $\mathrm{Si}$ in both soils and plants on ecosystems and global processes. These intricate feedback mechanisms in ecosystems make $\mathrm{Si}$ in the soil-plant continuum an important phenomenon in ecosystem functioning and a driver of some ecosystem services. These far exceed soil and plants, also affecting herbivores and the atmosphere. What we need now to push the field forward is detailed, interdisciplinary research with a focus on (i) the development of a standard protocol for the determination of bioavailable $\mathrm{Si}$ in soils, (ii) the understanding of the modes of action of $\mathrm{Si}$ in plants, i.e., an understanding of the pathways that increase plants' resistance by $\mathrm{Si}$ accumulation, and (iii) gaining profound insights into the role of $\mathrm{Si}$ in influencing ecosystem structure and functioning. We consider our review as an urgent request and encouragement of future studies on these topics, which will help us to unravel the impact of Si on the soil-plant continuum, and thus on ecosystems.

Author Contributions: Conceptualization, O.K. and J.S.; writing-original draft preparation, O.K., D.P., D.K. and J.S.; writing—review and editing, O.K., D.P., N.B.P. and J.S.; visualization, O.K., D.P.; All authors have read and agreed to the published version of the manuscript.

Funding: This research was funded by the Israel Ministry of Science and Technology. D.P. was funded by the Deutsche Forschungsgemeinschaft (DFG) under grant PU 626/2-1.

Informed Consent Statement: Not applicable.

Acknowledgments: We thank J. Busse (ZALF, Germany) for the SEM-EDX analysis of the different Si-deposits of mature wheat leaves (Figure 2).

Conflicts of Interest: The authors declare no conflict of interest.

\section{References}

1. Katz, O. Silicon content is a plant functional trait: Implications in a changing world. Flora 2019, 254, 88-94. [CrossRef]

2. Cooke, J.; Leishman, M.R. Is plant ecology more siliceous than we realise? Trends Plant Sci. 2011, 16, 61-68. [CrossRef]

3. He, H.; Veneklaas, E.J.; Kuo, J.; Lambers, H. Physiological and ecological significance of biomineralization in plants. Trends Plant Sci. 2014, 19, 166-174. [CrossRef] [PubMed]

4. Epstein, E. The anomaly of silicon in plant biology. Proc. Natl. Acad. Sci. USA 1994, 91, 11-17. [CrossRef] [PubMed]

5. Putra, R.; Powell, J.R.; Hartley, S.E.; Johnson, S.N. Is it time to include legumes in plant silicon research? Funct. Ecol. 2020, 34 1142-1157. [CrossRef] 
6. Epstein, E. Silicon: Its manifold roles in plants. Ann. Appl. Biol. 2009, 155, 155-160. [CrossRef]

7. Frew, A.; Weston, L.A.; Reynolds, O.L.; Gurr, G.M. The role of silicon in plant biology: A paradigm shift in research approach. Ann. Bot. 2018, 121, 1265-1273. [CrossRef] [PubMed]

8. Richmond, K.E.; Sussman, M. Got silicon? The non-essential beneficial plant nutrient. Curr. Opin. Plant Biol. 2003, 6, 268-272. [CrossRef]

9. Farooq, M.A.; Dietz, K.J. Silicon as versatile player in plant and human biology: Overlooked and poorly understood. Front. Plant Sci. 2015, 6, 994. [CrossRef]

10. Meharg, C.; Meharg, A.A. Silicon, the silver bullet for mitigating biotic and abiotic stress, and improving grain quality, in rice? Environ. Exp. Bot. 2015, 120, 8-17. [CrossRef]

11. Raven, J.A. The transport and function of silicon in plants. Biol. Rev. 1983, 58, 179-207. [CrossRef]

12. Schoelynck, J.; Struyf, E. Silicon in aquatic vegetation. Funct. Ecol. 2016, 30, 1323-1330. [CrossRef]

13. Cooke, J.; Leishman, M.R. Consistent alleviation of abiotic stress with silicon addition: A meta-analysis. Funct. Ecol. 2016, 30, 1340-1357. [CrossRef]

14. Guntzer, F.; Keller, C.; Meunier, J.D. Benefits of plant silicon for crops: A review. Agron. Sustain. Dev. 2012, 32, 201-213. [CrossRef]

15. Ma, J.F.; Yamaji, N. Silicon uptake and accumulation in higher plants. Trends Plant Sci. 2006, 11, 392-397. [CrossRef]

16. Ma, J.F.; Yamaji, N. Functions and transport of silicon in plants. Cell. Mol. Life Sci. 2008, 65, 3049-3057. [CrossRef]

17. Sahebi, M.; Hanafi, M.M.; Siti Nor Akmar, A.; Rafii, M.Y.; Azizi, P.; Tengoua, F.F.; Nurul Mayzaitul Azwa, J.; Shabanimofrad, M. Importance of silicon and mechanisms of biosilica formation in plants. BioMed Res. Int. 2015, 2015, 396010. [CrossRef]

18. Katz, O. Beyond grasses: The potential benefits of studying silicon accumulation in non-grass species. Front. Plant Sci. 2014, 5, 376. [CrossRef]

19. Frings, P.J.; Clymans, W.; Jeppesen, E.; Lauridsen, T.L.; Struyf, E.; Conley, D.J. Lack of steady-state in the global biogeochemical Si cycle: Emerging evidence from lake Si sequestration. Biogeochemistry 2014, 117, 255-277. [CrossRef]

20. Keller, C.; Guntzer, F.; Barboni, D.; Labreuche, J.; Meunier, J.D. Impact of agriculture on the Si biogeochemical cycle: Input from phytolith studies. C. R. Geosci. 2012, 344, 739-746. [CrossRef]

21. Carey, J.C.; Fulweiler, R.W. The terrestrial silica pump. PLoS ONE 2012, 7, e52932. [CrossRef]

22. Cornelis, J.T.; Delvaux, B. Soil processes drive the biological silicon feedback loop. Funct. Ecol. 2016, 30, 1298-1310. [CrossRef]

23. Katz, O. Silica phytoliths in angiosperms: Phylogeny and early evolutionary history. New Phytol. 2015, 208, 642-646. [CrossRef] [PubMed]

24. Cooke, J.; Degabriel, J.L. Plant silicon interactions between organisms and the implications for ecosystems. Front. Plant Sci. 2016, 7, 1001. [CrossRef]

25. Schoelynck, J.; Müller, F.; Vandevenne, F.; Bal, K.; Barão, L.; Smis, A.; Opdekamp, W.; Meire, P.; Struyf, E. Silicon-Vegetation interaction in multiple ecosystems: A review. J. Veg. Sci. 2014, 25, 301-313. [CrossRef]

26. Schaller, J.; Puppe, D.; Kaczorek, D.; Ellerbrock, R.; Sommer, M. Silicon cycling in soils revisited. Plants 2021, 10, 295. [CrossRef]

27. Ehrenberg, C.G. Mikrogeologie: Das Erden und Felsen Schaffende Wirken des Unsichtbar Kleinen Selbständigen Lebens auf der Erde; L. Voss: Leipzig, Germany, 1854.

28. Powers, A.P. Historical review of European phytolith systematics. In Phytolith Systematics; Rapp, G.J., Mulholland, S.C., Eds.; Springer International Publishing: New York, NY, USA, 1992; pp. 15-35.

29. Darwin, C. An account of the fine dust which often falls on vessels in the Atlantic Ocean. Q. J. Geol. Soc. Lond. 1846, 2, 26-30. [CrossRef]

30. Struve, G.A. De Silicia in Plantis Nonnullis; University of Berlin: Berlin, Germany, 1835.

31. Davy, H. Elements of Agricultural Chemistry; John J. Griffin and Company: Glasgow, UK, 1846.

32. Sachs, J. Ergebnisse einiger neuerer untersuchungen uber die in pflanzen enthaltene Kieselsaure. Flora 1862, 33, 65-71.

33. Miliarakis, S. Die Verkieselung lebender Elementarorgane bei den Pflanzen; University Würzburg: Würzburg, Germany, 1884.

34. Kreuzhage, C.; Wolff, E. Bedeutung der kieselsäure für die entwicklung der haferpflanze. Landwirtsch. Versuchs-Stationen 1884, 30, 161-197.

35. von Marilaun, A.K. Pflanzenleben: Bd. Gestalt und Legen der Pflanze; Verlag des Bibliographischen Institut: Leipzig, Germany, 1887.

36. Stahl, E. Pflanzen und Schnecken: Eine Biologische Studie Über Die Schutzmittel der Pflanzen Gegen Schneckenfrass; G. Fischer: Jena, Germany, 1888.

37. Lemmermann, O.; Wießmann, H. Die ertragssteigernde wirkung der kieselsäure bei unzureichender phosphorsäureernährung der pflanzen. Zeitschrift für Pflanzenernährung und Düngung A Wissenschaftlicher Teil 1922, 1, 185-246. [CrossRef]

38. Lemmermann, O.; Wießmann, H.; Lemmermann, O. Weitere versuche über die ertragssteigernde wirkung der kieselsäure bei unzureichender phosphorsäuredüngung. Zeitschrift für Pflanzenernährung und Düngung A Wissenschaftlicher Teil 1924, 3, 185-197. [CrossRef]

39. Wießmann, O.L.U.; Sammet, K.; Lemmermann, O. Untersuchungen über die ursache der ertragssteigernden wirkung der kieselsäure. Zeitschrift für Pflanzenernährung und Düngung A Wissenschaftlicher Teil 1925, 4, 265-315. [CrossRef]

40. Sommer, A.L. Studies Concerning the Essential Nature of Aluminum and Silicon for Plant Growth; University of California Press: Berkeley, CA, USA, 1926.

41. Ma, J.F.; Takahashi, E. Soil, Fertilizer, and Plant Silicon Research in Japan; Elsevier: Amsterdam, The Netherlands, 2002.

42. Onodera, I. Chemical studies on rice blast (1). J. Sci. Agric. Soc. 1917, 180, 606-617. 
43. Miyake, K.; Adachi, M. Chmische Untersucungen über die widerstandsfähigkeit der reisarten gegen die "imochi-krankheit": Zweiter bericht. der einflusz der wasserstoffionenkonzentration auf das wachstum des pilzes. J. Biochem. 1922. [CrossRef]

44. Kawashima, R. Influence of silica on rice blast disease. Jpn. J. Soil Sci. Plant Nutr. 1927, 1, 86-91.

45. Miyake, K.; Ikeda, M. Influence of silica application on rice blast. Jpn. J. Soil Sci. Plant Nutr. 1932, 6, 53-76.

46. Ishibashi, H. Influence of silica on the growth of rice plant. Jpn. J. Soil Sci. Plant Nutr. 1936, 10, $244-256$.

47. Ishibashi, H. The effect of silica on the growth of cultivated plants. V. The effect of silica on the growth of rice plants growing on soils of various depth. J. Sci. Soil Manure 1937, 11, 535-549.

48. Ishibashi, H. The eefct of silicic acid on the growth of rice plants. J. Sci. Soil Manure 1936, 10, 224-256.

49. Raleigh, G.J. Evidence for the essentiality of silicon for the beet plant. Plant Physiol. 1939. [CrossRef] [PubMed]

50. Wagner, F. The importance of silicic acid for the growth of some cultivated plants, their metabolism, and their susceptibility to true mildew. Phytopathol. Zeitschrift 1940, 12, 427-479.

51. Engel, W. Untersuchungen über die Kieselsäureverbindungen im Roggenhalm. Planta 1953, 41, 358-390. [CrossRef]

52. Holzapfel, L.; Engel, W. Beeinflussung der Kieselsäure-Aufnahme und-Abgabe bei Weizenpflanzen. Arch. Biochem. Biophys. 1959, 83, 268-274. [CrossRef]

53. Yoshida, S.; Ohnishi, Y.; Kitagishi, K. Histochemistry of silicon in rice plant: III. The presence of cuticle-silica double layer in the epidermal tissue. Soil Sci. Plant Nutr. 1962, 8, 1-5. [CrossRef]

54. Okuda, A.; Takahashi, E. Effects of silicon supply on the injuries due to excessive amount of $\mathrm{Fe}, \mathrm{Mn}, \mathrm{Cu}, \mathrm{As}, \mathrm{Al}, \mathrm{Co}$ of barley and rice plants. Jpn. J. Soil Sci. Plant Nutr. 1962, 33, 1-8.

55. Okuda, A.; Takahashi, E. Studies on the physiological role of silicon in crop plant. Part 3. Effect of various amount of silicon supply on the growth of rice plant and its nutrients uptake. J. Sci. Soil Manure 1961, 32, 533-537.

56. Lewin, J.; Reimann, B.E.F. Silicon and plant growth. Annu. Rev. Plant Physiol. 1969, 20, 289-304. [CrossRef]

57. Jones, L.H.P.; Handreck, K.A. Studies of silica in the oat plant-III. Uptake of silica from soils by the plant. Plant Soil 1965, 23, 79-96. [CrossRef]

58. Jones, L.H.P.; Handreck, K.A. Silica in soils, plants, and animals. Adv. Agron. 1967, 19, 107-149. [CrossRef]

59. Handreck, K.A.; Jones, L.H.P. Studies of silica in the oat plant-IV. Silica content of plant parts in relation to stage of growth, supply of silica, and transpiration. Plant Soil 1968, 29, 449-459. [CrossRef]

60. Jones, L.H.P.P.; Milne, A.A.; Wadham, S.M. Studies of silica in the oat plant. Plant Soil 1963, 18, 358-371. [CrossRef]

61. Jones, L.H.P.; Handreck, K.A. Uptake of silica by Trifolium incarnatum in relation to the concentration in the external solution and to transpiration. Plant Soil 1969, 30, 71-80. [CrossRef]

62. Sangster, A.G. Characteristics of silica deposition in Digitaria sanguinalis (L.) scop. (Crabgrass). Ann. Bot. 1977, 41, 341-350. [CrossRef]

63. Sangster, A.G. Intracellular silica deposition in immature leaves in three species of the Gramineae. Ann. Bot. 1970, 34, $245-257$. [CrossRef]

64. Parry, D.W.; Smithson, F. Silicification of bulliform cells in grasses. Nature 1958, 181, 1549-1550. [CrossRef]

65. Sangster, A.G.; Parry, D.W. Ultrastructure of silica deposits in higher plants. In Silicon and Siliceous Structures in Biological Systems; Simpson, T.L., Volcani, B.E., Eds.; Springer: New York, NY, USA, 1981; pp. 383-407.

66. Parry, D.W.; Kelso, M. The distribution of silicon deposits in the roots of Molinia caerulea (L.) Moench. and Sorghum bicolor (L.) Moench. Ann. Bot. 1975, 39, 995-1001. [CrossRef]

67. Sangster, A.G.; Parry, D.W. Endodermal silicon deposits and their linear distribution in developing roots of Sorghum bicolor (L.) Moench. Ann. Bot. 1976, 40, 361-371. [CrossRef]

68. Blackman, E.; Parry, D.W. Opaline silica deposition in rye (Secale cereale L.). Ann. Bot. 1968, 32, 199-206. [CrossRef]

69. Blackman, E. Observations on the development of the silica cells of the leaf sheath of wheat (Triticum aestivum). Can. J. Bot. 1969. [CrossRef]

70. Blackman, E. The pattern and sequence of opaline silica deposition in rye (Secale cereale L.). Ann. Bot. 1968, 32, 207-218. [CrossRef]

71. Blackman, E. Opaline silica bodies in the range grasses of southern Alberta. Can. J. Bot. 1971, 49, 769-781. [CrossRef]

72. Sauer, D.; Saccone, L.; Conley, D.J.; Herrmann, L.; Sommer, M. Review of methodologies for extracting plant-available and amorphous Si from soils and aquatic sediments. Biogeochemistry 2006, 80, 89-108. [CrossRef]

73. Matichenkov, V.V.; Bocharnikova, E.A. The relationship between silicon and soil physical and chemical properties. In Silicon in Agriculture; Datnoff, L.E., Snyder, G.H., Korndörfer, G.H., Eds.; Elsevier: Amsterdam, The Netherlands, 2001 ; pp. $209-219$.

74. Cornelis, J.T.; Delvaux, B.; Cardinal, D.; André, L.; Ranger, J.; Opfergelt, S. Tracing mechanisms controlling the release of dissolved silicon in forest soil solutions using Si isotopes and Ge/Si ratios. Geochim. Cosmochim. Acta 2010, 74, 3913-3924. [CrossRef]

75. Opfergelt, S.; de Bournonville, G.; Cardinal, D.; André, L.; Delstanche, S.; Delvaux, B. Impact of soil weathering degree on silicon isotopic fractionation during adsorption onto iron oxides in basaltic ash soils, Cameroon. Geochim. Cosmochim. Acta 2009, 73, 7226-7240. [CrossRef]

76. Dietzel, M. Dissolution of silicates and the stability of polysilicic acid. Geochim. Cosmochim. Acta 2000, 64, 3275-3281. [CrossRef]

77. Belton, D.J.; Deschaume, O.; Perry, C.C. An overview of the fundamentals of the chemistry of silica with relevance to biosilicification and technological advances. FEBS J. 2012, 279, 1710-1720. [CrossRef]

78. Dietzel, M. Interaction of polysilicic and monosilicic acid with mineral surfaces. In Water-Rock Interaction; Stober, I., Bucher, K., Eds.; Springer: Dordrecht, The Netherlands, 2002; pp. 207-235. 
79. Pallavi, T.; Prakash, N.B. Pools of silicon in soils and their contribution to rice. J. Indian Soc. Soil Sci. 2019, 67, 211-220. [CrossRef]

80. Majumdar, S.; Prakash, N.B. Quantification of amorphous silicon by optimizing the $1 \%$ Na2CO3 method from intensively cultivated rice and sugarcane soils in a tropical climate. Silicon 2020, 12, 2989-3003. [CrossRef]

81. Reithmaier, G.M.S.; Knorr, K.H.; Arnhold, S.; Planer-Friedrich, B.; Schaller, J. Enhanced silicon availability leads to increased methane production, nutrient and toxicant mobility in peatlands. Sci. Rep. 2017, 7, 8728. [CrossRef] [PubMed]

82. Sigg, L.; Stumm, W. The interaction of anions and weak acids with the hydrous goethite $(\alpha-\mathrm{FeOOH})$ surface. Colloids Surf. 1981, 2, 101-117. [CrossRef]

83. Schaller, J.; Faucherre, S.; Joss, H.; Obst, M.; Goeckede, M.; Planer-Friedrich, B.; Peiffer, S.; Gilfedder, B.; Elberling, B. Silicon increases the phosphorus availability of Arctic soils. Sci. Rep. 2019, 9, 449. [CrossRef] [PubMed]

84. Ma, J.F.; Takahashi, E. Effect of silicate on phosphate availability for rice in a P-deficient soil. Plant Soil 1991, 133, 151-155. [CrossRef]

85. Neu, S.; Schaller, J.; Dudel, E.G. Silicon availability modifies nutrient use efficiency and content, C:N:P stoichiometry, and productivity of winter wheat (Triticum aestivum L.). Sci. Rep. 2017, 7, 40829. [CrossRef] [PubMed]

86. Taylor, P. Interactions of Silica with Iron Oxides: Effects on Oxide Transformations and Sorption Properties; Whiteshell Laboratories: Pinawa, MB, Canada, 1995.

87. Meunier, J.D.; Sandhya, K.; Prakash, N.B.; Borschneck, D.; Dussouillez, P. pH as a proxy for estimating plant-available Si? A case study in rice fields in Karnataka (South India). Plant Soil 2018, 432, 143-155. [CrossRef]

88. Schaller, J.; Frei, S.; Rohn, L.; Gilfedder, B.S. Amorphous silica controls water storage capacity and phosphorus mobility in soils. Front. Environ. Sci. 2020, 8, 94. [CrossRef]

89. Dol Hamid, R.; Swedlund, P.J.; Song, Y.; Miskelly, G.M. Ionic strength effects on silicic acid (H4SiO4) sorption and oligomerization on an iron oxide surface: An interesting interplay between electrostatic and chemical forces. Langmuir 2011, 27, 12930-12937. [CrossRef] [PubMed]

90. Pokrovski, G.S.; Schott, J.; Farges, F.; Hazemann, J.L. Iron (III)-silica interactions in aqueous solution: Insights from X-ray absorption fine structure spectroscopy. Geochim. Cosmochim. Acta 2003, 67, 3559-3573. [CrossRef]

91. Xu, D.; Gao, T.; Fang, X.; Bu, H.; Li, Q.; Wang, X.; Zhang, R. Silicon addition improves plant productivity and soil nutrient availability without changing the grass:legume ratio response to N fertilization. Sci. Rep. 2020, 10, 10295. [CrossRef] [PubMed]

92. Bhat, J.A.; Shivaraj, S.M.; Singh, P.; Navadagi, D.B.; Tripathi, D.K.; Dash, P.K.; Solanke, A.U.; Sonah, H.; Deshmukh, R. Role of silicon in mitigation of heavy metal stresses in crop plants. Plants 2019, 8, 71. [CrossRef]

93. Li, L.; Zheng, C.; Fu, Y.; Wu, D.; Yang, X.; Shen, H. Silicate-Mediated alleviation of Pb toxicity in banana grown in Pb-contaminated soil. Biol. Trace Elem. Res. 2012, 145, 101-108. [CrossRef]

94. Exley, C.; Guerriero, G.; Lopez, X. Silicic acid: The omniscient molecule. Sci. Total Environ. 2019, 665, 432-437. [CrossRef]

95. Pačes, T. Reversible control of aqueous aluminum and silica during the irreversible evolution of natural waters. Geochim. Cosmochim. Acta 1978, 42, 1487-1493. [CrossRef]

96. Beardmore, J.; Lopez, X.; Mujika, J.I.; Exley, C. What is the mechanism of formation of hydroxyaluminosilicates? Sci. Rep. 2016, 6, 30913. [CrossRef]

97. Zhang, S.; Li, S.; Ding, X.; Li, F.; Liu, C.; Liao, X.; Wang, R. Silicon mediated the detoxification of Cr on pakchoi (Brassica chinensis L.) in Cr-contaminated soil. J. Food Agric. Environ. 2013, 11, 814-819. [CrossRef]

98. Shim, J.; Shea, P.J.; Oh, B.T. Stabilization of heavy metals in mining site soil with silica extracted from corn rob. Water. Air. Soil Pollut. 2014, 225, 2152. [CrossRef]

99. Da Cunha, K.P.V.; Do Nascimento, C.W.A.; Da Silva, A.J. Silicon alleviates the toxicity of cadmium and zinc for maize (Zea mays L.) grown on a contaminated soil. J. Plant Nutr. Soil Sci. 2008, 171, 849-853. [CrossRef]

100. Zachara, J.M.; Girvin, D.C.; Schmidt, R.L.; Resch, C.T. Chromate adsorption on amorphous iron oxyhydroxide in the presence of major groundwater ions. Environ. Sci. Technol. 1987, 21, 589-594. [CrossRef]

101. Gutiérrez-Castorena, M.D.C.; Stoops, G.; Ortiz Solorio, C.A.; López Avila, G. Amorphous silica materials in soils and sediments of the Ex-Lago de Texcoco, Mexico: An explanation for its subsidence. Catena 2005, 60, 205-226. [CrossRef]

102. Iler, R.K. Surface and Colloid Science; John Wiley \& Sons: Toronto, ON, Canada, 1973.

103. Schaller, J.; Cramer, A.; Carminati, A.; Zarebanadkouki, M. Biogenic amorphous silica as main driver for plant available water in soils. Sci. Rep. 2020, 10, 2424. [CrossRef]

104. Liang, Y.; Si, J.; Römheld, V. Silicon uptake and transport is an active process in Cucumis sativus. New Phytol. 2005, 167, 797-804. [CrossRef] [PubMed]

105. Henriet, C.; Draye, X.; Oppitz, I.; Swennen, R.; Delvaux, B. Effects, distribution and uptake of silicon in banana (Musa spp.) under controlled conditions. Plant Soil 2006, 287, 359-374. [CrossRef]

106. Faisal, S.; Callis, K.L.; Slot, M.; Kitajima, K. Transpiration-dependent passive silica accumulation in cucumber (Cucumis sativus) under varying soil silicon availability. Botany 2012, 90, 1058-1064. [CrossRef]

107. Mitani, N.; Ma, J.F. Uptake system of silicon in different plant species. J. Exp. Bot. 2005, 56, 1255-1261. [CrossRef]

108. Piperno, D.R.; Holst, I.; Wessel-Beaver, L.; Andres, T.C. Evidence for the control of phytolith formation in Cucurbita fruits by the hard rind (Hr) genetic locus: Archaeological and ecological implications. Proc. Natl. Acad. Sci. USA 2002, 99, 10923-10928. [CrossRef] 
109. Ma, J.F.; Tamai, K.; Yamaji, N.; Mitani, N.; Konishi, S.; Katsuhara, M.; Ishiguro, M.; Murata, Y.; Yano, M. A silicon transporter in rice. Nature 2006, 440, 688-691. [CrossRef] [PubMed]

110. Ma, J.F.; Yamaji, N.; Mitani, N.; Tamai, K.; Konishi, S.; Fujiwara, T.; Katsuhara, M.; Yano, M. An efflux transporter of silicon in rice. Nature 2007, 448, 209-212. [CrossRef]

111. Yamaji, N.; Mitani, N.; Ma, J.F. A transporter regulating silicon distribution in rice shoots. Plant Cell 2008, 20, 1381-1389. [CrossRef] [PubMed]

112. Ma, J.F.; Yamaji, N. A cooperative system of silicon transport in plants. Trends Plant Sci. 2015, 20, 435-442. [CrossRef]

113. Yamaji, N.; Ma, J.F. The node, a hub for mineral nutrient distribution in graminaceous plants. Trends Plant Sci. 2014, 19, 556-563. [CrossRef]

114. Yamaji, N.; Sakurai, G.; Mitani-Ueno, N.; Ma, J.F. Orchestration of three transporters and distinct vascular structures in node for intervascular transfer of silicon in rice. Proc. Natl. Acad. Sci. USA 2015, 112, 11401-11406. [CrossRef] [PubMed]

115. Yan, G.; Fan, X.; Tan, L.; Yin, C.; Li, T.; Liang, Y. Root silicon deposition and its resultant reduction of sodium bypass flow is modulated by OsLsi1 and OsLsi2 in rice. Plant Physiol. Biochem. 2021, 158, 219-227. [CrossRef]

116. Yan, G.C.; Nikolic, M.; Ye, M.J.; Xiao, Z.X.; Liang, Y.C. Silicon acquisition and accumulation in plant and its significance for agriculture. J. Integr. Agric. 2018, 17, 2138-2150. [CrossRef]

117. Deshmukh, R.K.; Vivancos, J.; Guérin, V.; Sonah, H.; Labbé, C.; Belzile, F.; Bélanger, R.R. Identification and functional characterization of silicon transporters in soybean using comparative genomics of major intrinsic proteins in Arabidopsis and rice. Plant Mol. Biol. 2013, 83, 303-315. [CrossRef] [PubMed]

118. Mitani, N.; Yamaji, N.; Ago, Y.; Iwasaki, K.; Ma, J.F. Isolation and functional characterization of an influx silicon transporter in two pumpkin cultivars contrasting in silicon accumulation. Plant J. 2011, 66, 231-240. [CrossRef] [PubMed]

119. Wang, H.S.; Yu, C.; Fan, P.P.; Bao, B.F.; Li, T.; Zhu, Z.J. Identification of two cucumber putative silicon transporter genes in cucumis sativus. J. Plant Growth Regul. 2015, 34, 332-338. [CrossRef]

120. Sahebi, M.; Hanafi, M.M.; Abdullah, S.N.A.; Rafii, M.Y.; Azizi, P.; Nejat, N.; Idris, A.S. Isolation and expression analysis of novel silicon absorption gene from roots of mangrove (Rhizophora apiculata) via suppression subtractive hybridization. BioMed Res. Int. 2014, 2014, 971985. [CrossRef] [PubMed]

121. Grégoire, C.; Rémus-Borel, W.; Vivancos, J.; Labbé, C.; Belzile, F.; Bélanger, R.R. Discovery of a multigene family of aquaporin silicon transporters in the primitive plant Equisetum arvense. Plant J. 2012, 72, 320-330. [CrossRef] [PubMed]

122. Trembath-Reichert, E.; Wilson, J.P.; McGlynn, S.E.; Fischer, W.W. Four hundred million years of silica biomineralization in land plants. Proc. Natl. Acad. Sci. USA 2015, 112, 5449-5454. [CrossRef]

123. Yamaji, N.; Ma, J.F. Spatial distribution and temporal variation of the rice silicon transporter Lsi1. Plant Physiol. 2007, 143, 1306-1313. [CrossRef]

124. Kumar, N.; Dubey, A.K.; Upadhyay, A.K.; Gautam, A.; Ranjan, R.; Srikishna, S.; Sahu, N.; Behera, S.K.; Mallick, S. GABA accretion reduces Lsi-1 and Lsi-2 gene expressions and modulates physiological responses in Oryza sativa to provide tolerance towards arsenic. Sci. Rep. 2017, 7, 8786. [CrossRef]

125. Chaiwong, N.; Bouain, N.; Prom-u-thai, C.; Rouached, H. Interplay between silicon and iron signaling pathways to regulate silicon transporter Lsi1 expression in rice. Front. Plant Sci. 2020, 11, 1065. [CrossRef]

126. Bokor, B.; Bokorová, S.; Ondoš, S.; Švubová, R.; Lukačová, Z.; Hýblová, M.; Szemes, T.; Lux, A. Ionome and expression level of Si transporter genes (Lsi1, Lsi2, and Lsi6) affected by Zn and Si interaction in maize. Environ. Sci. Pollut. Res. 2015, 22, 6800-6811. [CrossRef]

127. Lux, A.; Luxová, M.; Abe, J.; Tanimoto, E.; Hattori, T.; Inanaga, S. The dynamics of silicon deposition in the sorghum root endodermis. New Phytol. 2003, 158, 437-441. [CrossRef]

128. Hattori, T.; Inanaga, S.; Araki, H.; An, P.; Morita, S.; Luxová, M.; Lux, A. Application of silicon enhanced drought tolerance in Sorghum bicolor. Physiol. Plant. 2005, 123, 459-466. [CrossRef]

129. de Melo, S.P.; Korndörfer, G.H.; Korndörfer, C.M.; Lana, R.M.Q.; de Santana, D.G. Silicon accumulation and water deficit tolerance in Brachiaria grasses. Sci. Agric. 2003, 60, 755-759. [CrossRef]

130. Mayland, H.F.; Wright, J.L.; Sojka, R.E. Silicon accumulation and water uptake by wheat. Plant Soil 1991, 137, 191-199. [CrossRef]

131. Jenkins, E.; Jamjoum, K.; Nuimat, S.; Stafford, R.; Nortcliff, S.; Mithen, S. Identifying ancient water availability through phytolith analysis: An experimental approach. J. Archaeol. Sci. 2016, 73, 82-93. [CrossRef]

132. Jenkins, E.; Jamjoum, K.; Al Nuimat, S. Irrigation and phytolith formation: An experimental study. Water Life Civilis. 2011, 347-372. [CrossRef]

133. Rosen, A.M.; Weiner, S. Identifying ancient irrigation: A new method using opaline phytoliths from emmer wheat. J. Archaeol. Sci. 1994, 21, 125-132. [CrossRef]

134. Katz, O.; Lev-Yadun, S.; Bar (Kutiel), P. Plant silicon and phytolith contents as affected by water availability and herbivory: Integrating laboratory experimentation and natural habitat studies. Silicon 2018, 10, 2387-2389. [CrossRef]

135. Euliss, K.W.; Dorsey, B.L.; Benke, K.C.; Banks, M.K.; Schwab, A.P. The use of plant tissue silica content for estimating transpiration. Ecol. Eng. 2005, 25, 343-348. [CrossRef]

136. Katz, O.; Lev-Yadun, S.; Pua Bar, K. Plasticity and variability in the patterns of phytolith formation in Asteraceae species along a large rainfall gradient in Israel. Flora 2013, 208, 438-444. [CrossRef] 
137. Katz, O.; Lev-Yadun, S.; Bar, P. Do phytoliths play an antiherbivory role in southwest Asian Asteraceae species and to what extent? Flora 2014, 209, 349-358. [CrossRef]

138. Johnston, A.; Bezeau, L.M.; Smoliak, S. Variation in silica content of range grasses. Can. J. Plant Sci. 1967, 47, 65-71. [CrossRef]

139. Webb, E.A.; Longstaffe, F.J. The relationship between phytolith- and plant-water $\delta 18 \mathrm{O}$ values in grasses. Geochim. Cosmochim. Acta 2003, 67, 1437-1449. [CrossRef]

140. Frew, A.; Allsopp, P.G.; Gherlenda, A.N.; Johnson, S.N. Increased root herbivory under elevated atmospheric carbon dioxide concentrations is reversed by silicon-based plant defences. J. Appl. Ecol. 2017, 54, 1310-1319. [CrossRef]

141. Takahashi, N.; Isogai, A.; Ling, P.P.; Kato, Y.; Kurata, K. Effects of elevated atmospheric carbon dioxide concentration on silica deposition in rice (Oryza sativa L.) panicle. Plant Prod. Sci. 2008, 11, 307-315. [CrossRef]

142. Li, N.N.; Jie, D.M.; Ge, Y.; Guo, J.X.; Liu, H.Y.; Liu, L.D.; Qiao, Z.H. Response of phytoliths in Phragmites communis to elevated CO2 concentration in Songnen Grassland, China. Quat. Int. 2014, 321, 97-104. [CrossRef]

143. Hartley, S.E.; DeGabriel, J.L. The ecology of herbivore-induced silicon defences in grasses. Funct. Ecol. 2016, $30,1311-1322$. [CrossRef]

144. Massey, F.P.; Roland Ennos, A.; Hartley, S.E. Herbivore specific induction of silica-based plant defences. Oecologia 2007, 152, 677-683. [CrossRef] [PubMed]

145. Kvedaras, O.L.; An, M.; Choi, Y.S.; Gurr, G.M. Silicon enhances natural enemy attraction and biological control through induced plant defences. Bull. Entomol. Res. 2010, 100, 367-371. [CrossRef]

146. Islam, T.; Moore, B.D.; Johnson, S.N. Novel evidence for systemic induction of silicon defences in cucumber following attack by a global insect herbivore. Ecol. Entomol. 2020, 45, 1373-1381. [CrossRef]

147. Johnson, S.N.; Reynolds, O.L.; Gurr, G.M.; Esveld, J.L.; Moore, B.D.; Tory, G.J.; Gherlenda, A.N. When resistance is futile, tolerate instead: Silicon promotes plant compensatory growth when attacked by above- and belowground herbivores. Biol. Lett. 2019, 15, 20190361. [CrossRef] [PubMed]

148. Soininen, E.M.; Bråthen, K.A.; Jusdado, J.G.H.; Reidinger, S.; Hartley, S.E. More than herbivory: Levels of silica-based defences in grasses vary with plant species, genotype and location. Oikos 2013, 122, 30-41. [CrossRef]

149. Massey, F.P.; Ennos, A.R.; Hartley, S.E. Grasses and the resource availability hypothesis: The importance of silica-based defences. J. Ecol. 2007, 95, 414-424. [CrossRef]

150. McNaughton, S.J.; Tarrants, J.L. Grass leaf silicification: Natural selection for an inducible defense against herbivores. Proc. Natl. Acad. Sci. USA 1983, 80, 790-791. [CrossRef]

151. Bañuelos, M.J.; Obeso, J.R. Effect of grazing history, experimental defoliation, and genotype on patterns of silicification in Agrostis tenuis Sibth. Ecoscience 2000, 7, 45-50. [CrossRef]

152. Garbuzov, M.; Reidinger, S.; Hartley, S.E. Interactive effects of plant-available soil silicon and herbivory on competition between two grass species. Ann. Bot. 2011, 108, 1355-1363. [CrossRef] [PubMed]

153. Quigley, K.M.; Anderson, T.M. Leaf silica concentration in Serengeti grasses increases with watering but not clipping: Insights from a common garden study and literature review. Front. Plant Sci. 2014, 5, 568. [CrossRef]

154. Cid, M.S.; Detling, J.K.; Brizuela, M.A.; Whicker, A.D. Patterns in grass silicification: Response to grazing history and defoliation. Oecologia 1989, 80, 268-271. [CrossRef] [PubMed]

155. Kindomihou, V.M.; Dagbénonbakin, G.D.; Bognonkpe, J.P.; Sinsin, B.A.; Meerts, P.J. Silica concentration is related to leaf traits but not to a specific anatomical tissue in tropical fodder grass species. Eur. J. Sci. Res. 2011, 62, 559-570.

156. Brizuela, M.A.; Detling, J.K.; Cid, M.S. Silicon concentration of grasses growing in sites with different grazing histories. Ecology 1986, 67, 1098-1101. [CrossRef]

157. Massey, F.P.; Smith, M.J.; Lambin, X.; Hartley, S.E. Are silica defences in grasses driving vole population cycles? Biol. Lett. 2008, 4, 419-422. [CrossRef] [PubMed]

158. Huitu, O.; Forbes, K.M.; Helander, M.; Julkunen-Tiitto, R.; Lambin, X.; Saikkonen, K.; Stuart, P.; Sulkama, S.; Hartley, S. Silicon, endophytes and secondary metabolites as grass defenses against mammalian herbivores. Front. Plant Sci. 2014, 5, 478. [CrossRef] [PubMed]

159. Reynolds, J.J.H.; Lambin, X.; Massey, F.P.; Reidinger, S.; Sherratt, J.A.; Smith, M.J.; White, A.; Hartley, S.E. Delayed induced silica defences in grasses and their potential for destabilising herbivore population dynamics. Oecologia 2012, 170, 445-456. [CrossRef] [PubMed]

160. Melzer, S.E.; Knapp, A.K.; Kirkman, K.P.; Smith, M.D.; Blair, J.M.; Kelly, E.F. Fire and grazing impacts on silica production and storage in grass dominated ecosystems. Biogeochemistry 2010, 97, 263-278. [CrossRef]

161. Hartley, S.E. Round and round in cycles? Silicon-based plant defences and vole population dynamics. Funct. Ecol. 2015, 29, 151-153. [CrossRef]

162. Clymans, W.; Conley, D.J.; Battles, J.J.; Frings, P.J.; Koppers, M.M.; Likens, G.E.; Johnson, C.E. Silica uptake and release in live and decaying biomass in a northern hardwood forest. Ecology 2016, 97, 3044-3057. [CrossRef]

163. Narayanaswamy, C.; Prakash, N.B. Evaluation of selected extractants for plant-available silicon in rice soils of Southern India. Commun. Soil Sci. Plant Anal. 2010, 41, 977-989. [CrossRef]

164. Narayanaswamy, C.; Prakash, N.B. Calibration and categorization of plant available silicon in rice soils of South India. J. Plant Nutr. 2009, 32, 1237-1254. [CrossRef] 
165. DeMaster, D.J. The supply and accumulation of silica in the marine environment. Geochim. Cosmochim. Acta 1981, 45, 1715-1732. [CrossRef]

166. Puppe, D.; Höhn, A.; Kaczorek, D.; Wanner, M.; Wehrhan, M.; Sommer, M. How big is the influence of biogenic silicon pools on short-term changes in water-soluble silicon in soils? Implications from a study of a 10-year-old soil-plant system. Biogeosciences 2017, 14, 5239-5252. [CrossRef]

167. Chao, T.T.; Sanzolone, R.F. Decomposition techniques. J. Geochem. Explor. 1992, 44, 65-106. [CrossRef]

168. Nakamura, R.; Cornelis, J.T.; de Tombeur, F.; Nakagawa, M.; Kitajima, K. Comparative analysis of borate fusion versus sodium carbonate extraction for quantification of silicon contents in plants. J. Plant Res. 2020, 133, 271-277. [CrossRef] [PubMed]

169. Guntzer, F.; Keller, C.; Meunier, J.D. Determination of the silicon concentration in plant material using Tiron extraction. New Phytol. 2010, 188, 902-906. [CrossRef] [PubMed]

170. Reidinger, S.; Ramsey, M.H.; Hartley, S.E. Rapid and accurate analyses of silicon and phosphorus in plants using a portable X-ray fluorescence spectrometer. New Phytol. 2012, 195, 699-706. [CrossRef]

171. Alexandre, A.; Meunier, J.-D.; Colin, F.; Koud, J.-M. Plant impact on the biogeochemical cycle of silicon and related weathering processes. Geochim. Cosmochim. Acta 1997, 61, 677-682. [CrossRef]

172. Hodson, M.J.; White, P.J.; Mead, A.; Broadley, M.R. Phylogenetic variation in the silicon composition of plants. Ann. Bot. 2005, 96, 1027-1046. [CrossRef] [PubMed]

173. Prychid, C.J.; Rudall, P.J.; Gregory, M. Systematics and biology of silica bodies in monocotyledons. Bot. Rev. 2003, 69, 377-440. [CrossRef]

174. Piperno, D.R. The production, deposition, and dissolution of phytoliths. Phytolith Anal. 1988, 11-49. [CrossRef]

175. Zotz, G. The systematic distribution of vascular epiphytes-a critical update. Bot. J. Linn. Soc. 2013, 171, 453-481. [CrossRef]

176. Thummel, R.V.; Brightly, W.H.; Strömberg, C.A.E. Evolution of phytolith deposition in modern bryophytes, and implications for the fossil record and influence on silica cycle in early land plant evolution. New Phytol. 2019, 221, 2273-2285. [CrossRef] [PubMed]

177. Mazumdar, J. Phytoliths of pteridophytes. S. Afr. J. Bot. 2011, 77, 10-19. [CrossRef]

178. Nguyen, M.N.; Meharg, A.A.; Carey, M.; Dultz, S.; Marone, F.; Cichy, S.B.; Tran, C.T.; Le, G.H.; Mai, N.T.; Nguyen, T.T.H. Fern, Dicranopteris linearis, derived phytoliths in soil: Morphotypes, solubility and content in relation to soil properties. Eur. J. Soil Sci. 2019, 70, 507-517. [CrossRef]

179. Golokhvast, K.S.; Seryodkin, I.V.; Bulakh, E.M.; Chaika, V.V.; Zakharenko, A.M.; Kholodov, A.S.; Pamirsky, I.E.; Chung, G. Mycolith (fungal phytolith) morphotypes and biosilification of proteins in wood-destroying and pileate fungi. Bot. Pacifica 2018, 7, 63-70. [CrossRef]

180. Mizutani, T.; Nagase, H.; Fujiwara, N.; Ogoshi, H. Silicic acid polymerization catalyzed by amines and polyamines. Bull. Chem. Soc. Jpn. 1998, 71, 2017-2022. [CrossRef]

181. Coradin, T.; Livage, J. Effect of some amino acids and peptides on silicic acid polymerization. Colloids Surf. B Biointerfaces 2001, 21, 329-336. [CrossRef]

182. Kauss, H.; Seehaus, K.; Franke, R.; Gilbert, S.; Dietrich, R.A.; Kröger, N. Silica deposition by a strongly cationic proline-rich protein from systemically resistant cucumber plants. Plant J. 2003, 33, 87-95. [CrossRef]

183. Mann, S.; Perry, C.C. Structural aspects of biogenic silica. Ciba Found. Symp. 1986, 121, 40-58. [CrossRef]

184. Harrison, C.C. Evidence for intramineral macromolecules containing protein from plant silicas. Phytochemistry 1996, 41, 37-42. [CrossRef]

185. Ma, J.; Cai, H.; He, C.; Zhang, W.; Wang, L. A hemicellulose-bound form of silicon inhibits cadmium ion uptake in rice (Oryza sativa) cells. New Phytol. 2015, 206, 1063-1074. [CrossRef]

186. Perry, C.C.; Keeling-Tucker, T. Biosilicification: The role of the organic matrix in structure control. J. Biol. Inorg. Chem. 2000, 5, 537-550. [CrossRef]

187. Currie, H.A.; Perry, C.C. Silica in plants: Biological, biochemical and chemical studies. Ann. Bot. 2007, 100, 1383-1389. [CrossRef] [PubMed]

188. Peleg, Z.; Saranga, Y.; Fahima, T.; Aharoni, A.; Elbaum, R. Genetic control over silica deposition in wheat awns. Physiol. Plant. 2010, 140, 10-20. [CrossRef]

189. Hodson, M.J. The development of phytoliths in plants and its influence on their chemistry and isotopic composition. Implications for palaeoecology and archaeology. J. Archaeol. Sci. 2016, 68, 62-69. [CrossRef]

190. Sakai, W.S.; Thom, M. Localization of silicon in specific cell wall layers of the stomatal apparatus of sugar cane by use of energy dispersive x-ray analysis. Ann. Bot. 1979, 44, 245-248. [CrossRef]

191. Zhang, C.; Wang, L.; Zhang, W.; Zhang, F. Do lignification and silicification of the cell wall precede silicon deposition in the silica cell of the rice (Oryza sativa L.) leaf epidermis? Plant Soil 2013, 372, 137-149. [CrossRef]

192. He, C.; Ma, J.; Wang, L. A hemicellulose-bound form of silicon with potential to improve the mechanical properties and regeneration of the cell wall of rice. New Phytol. 2015, 206, 1051-1062. [CrossRef] [PubMed]

193. Ueno, O.; Agarie, S. Silica deposition in cell walls of the stomatal apparatus of rice leaves. Plant Prod. Sci. 2005, 8, 71-73. [CrossRef]

194. He, C.; Wang, L.; Liu, J.; Liu, X.; Li, X.; Ma, J.; Lin, Y.; Xu, F. Evidence for "silicon" within the cell walls of suspension-cultured rice cells. New Phytol. 2013, 200, 700-709. [CrossRef] 
195. Rudall, P.J.; Prychid, C.J.; Gregory, T. Epidermal patterning and silica phytoliths in grasses: An evolutionary history. Bot. Rev. 2014, 80, 59-71. [CrossRef]

196. Schaller, J.; Brackhage, C.; Paasch, S.; Brunner, E.; Bäucker, E.; Dudel, E.G. Silica uptake from nanoparticles and silica condensation state in different tissues of Phragmites australis. Sci. Total Environ. 2013, 442, 6-9. [CrossRef] [PubMed]

197. Neumann, K.; Strömberg, C.A.E.; Ball, T.; Albert, R.M.; Vrydaghs, L.; Cummings, L.S. International Code for Phytolith Nomenclature (ICPN) 2.0. Ann. Bot. 2019, 124, 189-199. [CrossRef]

198. Yoshida, S.; Ohnishi, Y.; Kitagishi, K. Chemical forms, mobility and deposition of silicon in rice plant. Soil Sci. Plant Nutr. 1962, 8 , 15-21. [CrossRef]

199. Matichenkov, V.V.; Bocharnikova, E.A.; Kosobryukhov, A.A.; Biel, K.Y. Mobile forms of silicon in plants. Dokl. Biol. Sci. 2008, 418, 39-40. [CrossRef]

200. Motomura, H.; Fujii, T.; Suzuki, M. Silica deposition in relation to ageing of leaf tissues in Sasa veitchii (Carrière) Rehder (Poaceae: Bambusoideae). Ann. Bot. 2004, 93, 235-248. [CrossRef]

201. Fernández Honaine, M.; Osterrieth, M.L. Silicification of the adaxial epidermis of leaves of a panicoid grass in relation to leaf position and section and environmental conditions. Plant Biol. 2012, 14, 596-604. [CrossRef] [PubMed]

202. Hodson, M.J.; Sangster, A.G.; Parry, D.W. An ultrastructural study on the developmental phases and silicification of the glumes of Phalaris canariensis L. Ann. Bot. 1985, 55, 649-665. [CrossRef]

203. Kaufman, P.B.; Petering, L.B.; Smith, J.G. Ultrastructural development of cork-silica cell pairs in Avena internodal epidermis. Bot. Gaz. 1970, 131, 173-185. [CrossRef]

204. Hodson, M.J.; Bell, A. The mineral relations of the lemma of Phalaris canariensis L., with particular reference to its silicified macrohairs. Isr. J. Bot. 1986, 35, 241-253. [CrossRef]

205. Lanning, F.C.; Eleuterius, L.N. Silica and ash in tissues of some coastal plants. Ann. Bot. 1983, 51, 835-850. [CrossRef]

206. Fernández Honaine, M.; Borrelli, N.L.; Osterrieth, M.; Del Rio, L. Leaf and culm silicification of Pampas grass (Cortaderia selloana) developed on different soils from Pampean region, Argentina. Aust. J. Bot. 2017, 65, 1-10. [CrossRef]

207. Schaller, J.; Brackhage, C.; Gessner, M.O.; Bäuker, E.; Gert Dudel, E. Silicon supply modifies C:N:P stoichiometry and growth of Phragmites australis. Plant Biol. 2012, 14, 392-396. [CrossRef] [PubMed]

208. Albert, R.M.; Shahack-Gross, R.; Cabanes, D.; Gilboa, A.; Lev-Yadun, S.; Portillo, M.; Sharon, I.; Boaretto, E.; Weiner, S. Phytolithrich layers from the Late Bronze and Iron Ages at Tel Dor (Israel): Mode of formation and archaeological significance. J. Archaeol. Sci. 2008, 35, 57-75. [CrossRef]

209. Tsartsidou, G.; Lev-Yadun, S.; Albert, R.M.; Miller-Rosen, A.; Efstratiou, N.; Weiner, S. The phytolith archaeological record: Strengths and weaknesses evaluated based on a quantitative modern reference collection from Greece. J. Archaeol. Sci. 2007, 34, 1262-1275. [CrossRef]

210. Portillo, M.; Kadowaki, S.; Nishiaki, Y.; Albert, R.M. Early Neolithic household behavior at Tell Seker al-Aheimar (Upper Khabur, Syria): A comparison to ethnoarchaeological study of phytoliths and dung spherulites. J. Archaeol. Sci. 2014, 42, 107-118. [CrossRef]

211. Das, S.; Ghosh, R.; Paruya, D.K.; Yao, Y.F.; Li, C.S.; Bera, S. Phytolith spectra in respiratory aerial roots of some mangrove plants of the Indian Sunderbans and its efficacy in ancient deltaic environment reconstruction. Quat. Int. 2014, 325, 179-196. [CrossRef]

212. Schoelynck, J.; Bal, K.; Puijalon, S.; Meire, P.; Struyf, E. Hydrodynamically mediated macrophyte silica dynamics. Plant Biol. 2012, 14, 997-1005. [CrossRef]

213. Lanning, F.C.; Eleuterius, L.N. Silica deposition in some C3 and C4 species of grasses, sedges and composites in the USA. Ann. Bot. 1989, 64, 395-410. [CrossRef]

214. Sangster, A.G.; Hodson, M.J. Silica deposition in subterranean organs. In Phytolith Systematics: Emerging Issues; Rapp, G., Mulholland, S.C., Eds.; Springer: Boston, MA, USA, 1992; pp. 239-251.

215. Gallego, L.; Distel, R.A. Phytolith assemblages in grasses native to central Argentina. Ann. Bot. 2004, 94, 865-874. [CrossRef] [PubMed]

216. Novello, A.; Barboni, D. Grass inflorescence phytoliths of useful species and wild cereals from sub-Saharan Africa. J. Archaeol. Sci. 2015, 59, 10-22. [CrossRef]

217. Mercader, J.; Astudillo, F.; Barkworth, M.; Bennett, T.; Esselmont, C.; Kinyanjui, R.; Grossman, D.L.; Simpson, S.; Walde, D. Poaceae phytoliths from the Niassa Rift, Mozambique. J. Archaeol. Sci. 2010, 37, 1953-1967. [CrossRef]

218. Fahmy, A.G. Diversity of lobate phytoliths in grass leaves from the Sahel region, West Tropical Africa: Tribe Paniceae. Plant Syst. Evol. 2008, 270, 1-23. [CrossRef]

219. Golokhvast, K.S.; Seryodkin, I.V.; Chaika, V.V.; Zakharenko, A.M.; Pamirsky, I.E. Phytoliths in taxonomy of phylogenetic domains of plants. BioMed Res. Int. 2014, 2014, 648326. [CrossRef] [PubMed]

220. Ackermann, O.; Greenbaum, N.; Ayalon, A.; Bar-Matthews, M.; Boaretto, E.; Bruins, H.J.; Cabanes, D.; Horwitz, L.K.; Neumann, F.H.; Porat, N.; et al. Using palaeo-environmental proxies to reconstruct natural and anthropogenic controls on sedimentation rates, Tell es-Safi/Gath, eastern Mediterranean. Anthropocene 2014, 8, 70-82. [CrossRef]

221. Alexandre, A.; Meunier, J.D.; Lézine, A.M.; Vincens, A.; Schwartz, D. Phytoliths: Indicators of grassland dynamics during the late Holocene in intertropical Africa. Palaeogeogr. Palaeoclimatol. Palaeoecol. 1997, 136, 213-229. [CrossRef]

222. Morgan-Edel, K.D.; Boston, P.J.; Spilde, M.N.; Reynolds, R.E. Phytoliths (plant-derived mineral bodies) as geobiological and climatic indicators in arid environments. New Mex. Geol. 2015, 37, 3-20. 
223. Piperno, D.R.; Sues, H.D. Dinosaurs dined on grass. Science 2005, 310, 1126-1128. [CrossRef] [PubMed]

224. Strömberg, C.A.E. Using phytolith assemblages to reconstruct the origin and spread of grass-dominated habitats in the great plains of North America during the late Eocene to early Miocene. Palaeogeogr. Palaeoclimatol. Palaeoecol. 2004, 207, 239-275. [CrossRef]

225. Bremond, L.; Alexandre, A.; Véla, E.; Guiot, J. Advantages and disadvantages of phytolith analysis for the reconstruction of Mediterranean vegetation: An assessment based on modern phytolith, pollen and botanical data (Luberon, France). Rev. Palaeobot. Palynol. 2004, 129, 213-228. [CrossRef]

226. Bremond, L.; Alexandre, A.; Wooller, M.J.; Hély, C.; Williamson, D.; Schäfer, P.A.; Majule, A.; Guiot, J. Phytolith indices as proxies of grass subfamilies on East African tropical mountains. Glob. Planet. Chang. 2008, 61, 209-224. [CrossRef]

227. Zurro, D.; García-Granero, J.J.; Lancelotti, C.; Madella, M. Directions in current and future phytolith research. J. Archaeol. Sci. 2016, 68, 112-117. [CrossRef]

228. Morris, L.R.; West, N.E.; Baker, F.A.; Van Miegroet, H.; Ryel, R.J. Developing an approach for using the soil phytolith record to infer vegetation and disturbance regime changes over the past 200 years. Quat. Int. 2009, 193, 90-98. [CrossRef]

229. Hart, T.C. Issues and directions in phytolith analysis. J. Archaeol. Sci. 2016, 68, 24-31. [CrossRef]

230. Shillito, L.M. Grains of truth or transparent blindfolds? A review of current debates in archaeological phytolith analysis. Veg. Hist. Archaeobot. 2013, 22, 71-82. [CrossRef]

231. Prasad, V.; Strömberg, C.A.E.; Alimohammadian, H.; Sahni, A. Dinosaur coprolites and the early evolution of grasses and grazers Science 2005, 310, 1177-1180. [CrossRef] [PubMed]

232. Prasad, V.; Strömberg, C.A.E.; Leaché, A.D.; Samant, B.; Patnaik, R.; Tang, L.; Mohabey, D.M.; Ge, S.; Sahni, A. Late Cretaceous origin of the rice tribe provides evidence for early diversification in Poaceae. Nat. Commun. 2011, 2, 480. [CrossRef]

233. Katz, O. Extending the scope of Darwin's "abominable mystery": Integrative approaches to understanding angiosperm origins and species richness. Ann. Bot. 2018, 121, 1-8. [CrossRef]

234. Schaller, J.; Turner, B.L.; Weissflog, A.; Pino, D.; Bielnicka, A.W.; Engelbrecht, B.M.J. Silicon in tropical forests: Large variation across soils and leaves suggests ecological significance. Biogeochemistry 2018, 140, 161-174. [CrossRef]

235. Katz, O. Silicon and plant-animal interactions: Towards an evolutionary framework. Plants 2020, 9, 430. [CrossRef]

236. Zhu, Y.; Gong, H. Beneficial effects of silicon on salt and drought tolerance in plants. Agron. Sustain. Dev. 2014, $34,455-472$. [CrossRef]

237. Coskun, D.; Britto, D.T.; Huynh, W.Q.; Kronzucker, H.J. The role of silicon in higher plants under salinity and drought stress. Front. Plant Sci. 2016, 7, 1072. [CrossRef]

238. Wilkinson, R. Plant-Environment Interactions; Marcel Dekker: New York, NY, USA, 2000; ISBN 0824703774.

239. Munns, R. Comparative physiology of salt and water stress. Plant Cell Environ. 2002, 25, 239-250. [CrossRef]

240. Dakora, F.D.; Nelwamondo, A. Silicon nutrition promotes root growth and tissue mechanical strength in symbiotic cowpea. Funct. Plant Biol. 2003, 30, 947-953. [CrossRef] [PubMed]

241. Steudle, E.; Peterson, C.A. How does water get through roots? J. Exp. Bot. 1998, 49, 775-788. [CrossRef]

242. Gao, X.; Zou, C.; Wang, L.; Zhang, F. Silicon decreases transpiration rate and conductance from stomata of maize plants. J. Plant Nutr. 2006, 29, 1637-1647. [CrossRef]

243. Gao, X.; Zou, C.; Wang, L.; Zhang, F. Silicon improves water use efficiency in maize plants. J. Plant Nutr. 2004, $27,1457-1470$. [CrossRef]

244. Agarie, S.; Uchida, H.; Agata, W.; Kaufman, P.B. Effects of silicon on stomatal blue-light response in rice (Oryza sativa L.). Plant Prod. Sci. 1999, 2, 232-234. [CrossRef]

245. Shakoor, S.A. Silicon biomineralisation in plants: A tool to adapt global climate change. J. Res. Biol. Sci. $2014,1,1-3$.

246. Vandegeer, R.K.; Zhao, C.; Cibils-Stewart, X.; Wuhrer, R.; Hall, C.R.; Hartley, S.E.; Tissue, D.T.; Johnson, S.N. Silicon deposition on guard cells increases stomatal sensitivity as mediated by $\mathrm{K}+$ efflux and consequently reduces stomatal conductance. Physiol. Plant. 2020. [CrossRef]

247. Aston, M.J.; Jones, M.M. A study of the transpiration surfaces of Avena sterilis L. var. Algerian leaves using monosilicic acid as a tracer for water movement. Planta 1976, 130, 121-129. [CrossRef]

248. Harizanova, A.; Zlatev, Z.; Koleva, L. Effect of silicon on activity of antioxidant enzymes and photosynthesis in leaves of cucumber plants (Cucumis sativus L.). Türk Tarım ve Doğa Bilim. Derg. 2014, 1, 1812-1817.

249. Shen, X.; Zhou, Y.; Duan, L.; Li, Z.; Eneji, A.E.; Li, J. Silicon effects on photosynthesis and antioxidant parameters of soybean seedlings under drought and ultraviolet-B radiation. J. Plant Physiol. 2010, 167, 1248-1252. [CrossRef]

250. Thorne, S.J.; Hartley, S.E.; Maathuis, F.J.M. Is silicon a panacea for alleviating drought and salt stress in crops? Front. Plant Sci. 2020, 11, 1221. [CrossRef] [PubMed]

251. Wang, Y.; Zhang, B.; Jiang, D.; Chen, G. Silicon improves photosynthetic performance by optimizing thylakoid membrane protein components in rice under drought stress. Environ. Exp. Bot. 2019, 158, 117-124. [CrossRef]

252. Gong, H.; Zhu, X.; Chen, K.; Wang, S.; Zhang, C. Silicon alleviates oxidative damage of wheat plants in pots under drought. Plant Sci. 2005, 169, 313-321. [CrossRef]

253. Detmann, K.C.; Araújo, W.L.; Martins, S.C.V.; Sanglard, L.M.V.P.; Reis, J.V.; Detmann, E.; Rodrigues, F.Á.; Nunes-Nesi, A.; Fernie, A.R.; Damatta, F.M. Silicon nutrition increases grain yield, which, in turn, exerts a feed-forward stimulation of photosynthetic 
rates via enhanced mesophyll conductance and alters primary metabolism in rice. New Phytol. 2012, 196, 752-762. [CrossRef] [PubMed]

254. Agarie, S.; Agata, W.; Uchida, H.; Kubota, F.; Kaufman, P.B. Function of silica bodies in the epidermal system of rice (Oryza sativa L.): Testing the window hypothesis. J. Exp. Bot. 1996, 47, 655-660. [CrossRef] [PubMed]

255. Vandevenne, F.I.; Barão, A.L.; Schoelynck, J.; Smis, A.; Ryken, N.; Van Damme, S.; Meire, P.; Struyf, E. Grazers: Biocatalysts of terrestrial silica cycling. Proc. R. Soc. B Biol. Sci. 2013, 280. [CrossRef]

256. Carey, J.C.; Fulweiler, R.W. Human appropriation of biogenic silicon-the increasing role of agriculture. Funct. Ecol. 2016, 30, 1331-1339. [CrossRef]

257. Müller, F.; Struyf, E.; Hartmann, J.; Weiss, A.; Jensen, K. Impact of grazing management on silica export dynamics of wadden sea saltmarshes. Estuar. Coast. Shelf Sci. 2013, 127, 1-11. [CrossRef]

258. Struyf, E.; Smis, A.; van Damme, S.; Meire, P.; Conley, D.J. The global biogeochemical silicon cycle. Silicon $2009,1,207-213$. [CrossRef]

259. Struyf, E.; Conley, D.J. Emerging understanding of the ecosystem silica filter. Biogeochemistry 2012, 107, 9-18. [CrossRef]

260. Alexandre, A.; Bouvet, M.; Abbadie, L. The role of savannas in the terrestrial Si cycle: A case-study from Lamto, Ivory Coast. Glob. Planet. Chang. 2011, 78, 162-169. [CrossRef]

261. Viaroli, P.; Nizzoli, D.; Pinardi, M.; Rossetti, G.; Bartoli, M. Factors affecting dissolved silica concentrations, and DSi and DIN stoichiometry in a human impacted watershed (Po River, Italy). Silicon 2013, 5, 101-114. [CrossRef]

262. Jacobs, S.; Müller, F.; Teuchies, J.; Oosterlee, L.; Struyf, E.; Meire, P. The vegetation silica pool in a developing tidal freshwater marsh. Silicon 2013, 5, 91-100. [CrossRef]

263. Farmer, V.C.; Delbos, E.; Miller, J.D. The role of phytolith formation and dissolution in controlling concentrations of silica in soil solutions and streams. Geoderma 2005, 127, 71-79. [CrossRef]

264. Raven, J.A. Cycling silicon-The role of accumulation in plants. New Phytol. 2003, 158, 419-421. [CrossRef]

265. Klotzbücher, T.; Leuther, F.; Marxen, A.; Vetterlein, D.; Horgan, F.G.; Jahn, R. Forms and fluxes of potential plant-available silicon in irrigated lowland rice production (Laguna, the Philippines). Plant Soil 2015, 393, 177-191. [CrossRef]

266. Johnson, S.N.; Hartley, S.E.; Moore, B.D. Silicon defence in plants: Does herbivore identity matter? Trends Plant Sci. 2021. [CrossRef]

267. Massey, F.P.; Ennos, A.R.; Hartley, S.E. Silica in grasses as a defence against insect herbivores: Contrasting effects on folivores and a phloem feeder. J. Anim. Ecol. 2006, 75, 595-603. [CrossRef] [PubMed]

268. Shewmaker, G.E.; Mayland, H.F.; Rosenau, R.C.; Asay, K.H. Silicon in C-3 Grasses: Effects on forage quality and sheep preference. J. Range Manag. 1989, 42, 122-127. [CrossRef]

269. Gali-Muhtasib, H.U.; Smith, C.C.; Higgins, J.J. The effect of silica in grasses on the feeding behavior of the prairie vole, Microtus Ochrogaster. Ecology 1992, 73, 1724-1729. [CrossRef]

270. Chanas, B.; Pawlik, J.R. Does the skeleton of a sponge provide a defense against predatory reef fish? Oecologia 1996, 107, 225-231. [CrossRef] [PubMed]

271. Hartley, S.E.; Fitt, R.N.; McLarnon, E.L.; Wade, R.N. Defending the leaf surface: Intra- and inter-specific differences in silicon deposition in grasses in response to damage and silicon supply. Front. Plant Sci. 2015, 6, 35. [CrossRef]

272. Kvedaras, O.L.; Keeping, M.G.; Goebel, F.R.; Byrne, M.J. Larval performance of the pyralid borer Eldana saccharina Walker and stalk damage in sugarcane: Influence of plant silicon, cultivar and feeding site. Int. J. Pest Manag. 2007, 53, 183-194. [CrossRef]

273. Grime, J.P.; MacPherson-Stewart, S.F.; Dearman, R.S. An investigation of leaf palatability using the snail Cepaea nemoralis L. J. Ecol. 1968, 56, 405-420. [CrossRef]

274. Samuels, A.L.; Glass, A.D.M.; Ehret, D.L.; Menzies, J.G. Distribution of silicon in cucumber leaves during infection by powdery mildew fungus (Sphaerotheca fuliginea). Can. J. Bot. 1991, 69, 140-146. [CrossRef]

275. Samuels, A.L.; Glass, A.D.M.; Menzies, J.G.; Ehret, D.L. Silicon in cell walls and papillae of Cucumis sativus during infection by Sphaerotheca fuliginea. Physiol. Mol. Plant Pathol. 1994, 44, 237-242. [CrossRef]

276. Kim, S.G.; Kim, K.W.; Park, E.W.; Choi, D. Silicon-induced cell wall fortification of rice leaves: A possible cellular mechanism of enhanced host resistance to blast. Phytopathology 2002, 92, 10959-11103. [CrossRef]

277. Hall, C.R.; Dagg, V.; Waterman, J.M.; Johnson, S.N. Silicon alters leaf surface morphology and suppresses insect herbivory in a model grass species. Plants 2020, 9, 643. [CrossRef]

278. Li, Z.; Song, Z.; Yan, Z.; Hao, Q.; Song, A.; Liu, L.; Yang, X.; Xia, S.; Liang, Y. Silicon enhancement of estimated plant biomass carbon accumulation under abiotic and biotic stresses. A meta-analysis. Agron. Sustain. Dev. 2018, 38, 26. [CrossRef]

279. Ishizuka, Y. Physiology of the rice plant. Adv. Agron. 1971, 23, 241-315. [CrossRef]

280. Massey, F.P.; Hartley, S.E. Physical defences wear you down: Progressive and. J. Anim. Ecol. 2009, 78, 281-291. [CrossRef]

281. Mir, S.H.; Rashid, I.; Hussain, B.; Reshi, Z.A.; Assad, R.; Sofi, I.A.; Hodson, M.J.; Johnson, S.N.; Juma, G.; Mir, S.H.; et al. Silicon supplementation of rescuegrass reduces herbivory by a grasshopper. Front. Plant Sci. 2019, 671. [CrossRef]

282. Massey, F.P.; Hartley, S.E. Experimental demonstration of the antiherbivore effects of silica in grasses: Impacts on foliage digestibility and vole growth rates. Proc. R. Soc. B Biol. Sci. 2006, 273, 2299-2304. [CrossRef] [PubMed]

283. Rivals, F.; Takatsuki, S.; Albert, R.M.; Macià, L. Bamboo feeding and tooth wear of three sika deer (Cervus nippon) populations from northern Japan. J. Mammal. 2014, 95, 1043-1053. [CrossRef] 
284. Sanson, G.D.; Kerr, S.A.; Gross, K.A. Do silica phytoliths really wear mammalian teeth? J. Archaeol. Sci. 2007, 34, 526-531. [CrossRef]

285. Kaiser, T.M.; Braune, C.; Kalinka, G.; Schulz-Kornas, E. Nano-indentation of native phytoliths and dental tissues: Implications for herbivore-plant combat and dental wear proxies. Evol. Syst. 2018, 2, 55-63. [CrossRef]

286. Lev-Yadun, S.; Halpern, M. External and internal spines in plants insert pathogenic microorganisms into herbivore's tissues for defense. Microb. Ecol. Res. Trends 2008, 155-168.

287. Song, Z.; Liu, H.; Zhao, F.; Xu, C. Ecological stoichiometry of N:P:Si in China's grasslands. Plant Soil 2014, 380, 165-179. [CrossRef]

288. Frew, A.; Weston, L.A.; Gurr, G.M. Silicon reduces herbivore performance via different mechanisms, depending on host-plant species. Austral. Ecol. 2019, 44, 1092-1097. [CrossRef]

289. Schaller, J.; Schoelynck, J.; Struyf, E.; Meire, P. Silicon affects nutrient content and ratios of wetland plants. Silicon 2016, 8, 479-485. [CrossRef]

290. Hunt, J.W.; Dean, A.P.; Webster, R.E.; Johnson, G.N.; Ennos, A.R. A novel mechanism by which silica defends grasses against herbivory. Ann. Bot. 2008, 102, 653-656. [CrossRef] [PubMed]

291. Gutierrez, C.; Corbera, J.A.; Doreste, F.; Padrón, T.R.; Morales, M. Silica urolithiasis in the dromedary camel in a subtropical climate. Vet. Res. Commun. 2002, 26, 437-442. [CrossRef] [PubMed]

292. Bailey, C.B. Silica metabolism and silica urolithiasis in ruminants: A review. Can. J. Anim. Sci. 1981, 61, 219-235. [CrossRef]

293. Vicari, M.; Bazely, D.R. Do grasses fight back? The case for antiherbivore defences. Trends Ecol. Evol. 1993, 8, 137-141. [CrossRef]

294. Bhatt, T.; Coombs, M.; O'Neill, C. Biogenic silica fibre promotes carcinogenesis in mouse skin. Int. J. Cancer 1984, 34, 519-528. [CrossRef]

295. Cherif, M.; Asselin, A.; Belanger, R.R. Defence responses induced by soluble silicon in cucumber roots infected by Phytium spp. Phytopathology 1994, 84, 236-242. [CrossRef]

296. Cai, K.; Gao, D.; Luo, S.; Zeng, R.; Yang, J.; Zhu, X. Physiological and cytological mechanisms of silicon-induced resistance in rice against blast disease. Physiol. Plant. 2008, 134, 324-333. [CrossRef]

297. Fauteux, F.; Rémus-Borel, W.; Menzies, J.G.; Bélanger, R.R. Silicon and plant disease resistance against pathogenic fungi. FEMS Microbiol. Lett. 2005, 249, 1-6. [CrossRef]

298. Wang, M.; Gao, L.; Dong, S.; Sun, Y.; Shen, Q.; Guo, S. Role of silicon on plant-pathogen interactions. Front. Plant Sci. 2017,8 , 701. [CrossRef] [PubMed]

299. Rahman, A.; Wallis, C.M.; Uddin, W. Silicon-Induced systemic defense responses in perennial ryegrass against infection by Magnaporthe oryzae. Phytopathology 2015, 105, 748-757. [CrossRef] [PubMed]

300. Leroy, N.; De Tombeur, F.; Walgraffe, Y.; Cornélis, J.T.; Verheggen, F.J. Silicon and plant natural defenses against insect pests: Impact on plant volatile organic compounds and cascade effects on multitrophic interactions. Plants 2019, 8, 444. [CrossRef] [PubMed]

301. Fauteux, F.; Chain, F.; Belzile, F.; Menzies, J.G.; Bélanger, R.R. The protective role of silicon in the Arabidopsis-powdery mildew pathosystem. Proc. Natl. Acad. Sci. USA 2006, 103, 17554-17559. [CrossRef] [PubMed]

302. Schoelynck, J.; Bal, K.; Backx, H.; Okruszko, T.; Meire, P.; Struyf, E. Silica uptake in aquatic and wetland macrophytes: A strategic choice between silica, lignin and cellulose? New Phytol. 2010, 186, 385-391. [CrossRef]

303. Klotzbücher, T.; Klotzbücher, A.; Kaiser, K.; Vetterlein, D.; Jahn, R.; Mikutta, R. Variable silicon accumulation in plants affects terrestrial carbon cycling by controlling lignin synthesis. Glob. Chang. Biol. 2018, 24, e183-e189. [CrossRef]

304. Cooke, J.; Leishman, M.R. Tradeoffs between foliar silicon and carbon-based defences: Evidence from vegetation communities of contrasting soil types. Oikos 2012, 121, 2052-2060. [CrossRef]

305. Frew, A.; Powell, J.R.; Sallam, N.; Allsopp, P.G.; Johnson, S.N. Trade-Offs between silicon and phenolic defenses may explain enhanced performance of root herbivores on phenolic-rich plants. J. Chem. Ecol. 2016, 42, 768-771. [CrossRef] [PubMed]

306. Johnson, S.N.; Hartley, S.E. Elevated carbon dioxide and warming impact silicon and phenolic-based defences differently in native and exotic grasses. Glob. Chang. Biol. 2018, 24, 3886-3896. [CrossRef]

307. Schaller, J.; Brackhage, C.; Dudel, E.G. Silicon availability changes structural carbon ratio and phenol content of grasses. Environ. Exp. Bot. 2012, 77, 283-287. [CrossRef]

308. Biru, F.N.; Cazzonelli, C.I.; Elbaum, R.; Johnson, S.N. Contrasting effects of Miocene and Anthropocene levels of atmospheric $\mathrm{CO} 2$ on silicon accumulation in a model grass. Biol. Lett. 2020, 16, 20200608. [CrossRef]

309. Fulweiler, R.W.; Maguire, T.J.; Carey, J.C.; Finzi, A.C. Does elevated CO2 alter silica uptake in trees? Front. Plant Sci. 2015, 5, 793. [CrossRef]

310. Brightly, W.H.; Hartley, S.E.; Osborne, C.P.; Simpson, K.J.; Strömberg, C.A.E. High silicon concentrations in grasses are linked to environmental conditions and not associated with C4 photosynthesis. Glob. Chang. Biol. 2020, 26, 7128-7143. [CrossRef] [PubMed]

311. Cooke, J.; DeGabriel, J.L.; Hartley, S.E. The functional ecology of plant silicon: Geoscience to genes. Funct. Ecol. 2016, 30, 1270-1276. [CrossRef]

312. Sommer, M.; Kaczorek, D.; Kuzyakov, Y.; Breuer, J. Silicon pools and fluxes in soils and landscapes-A review. J. Plant Nutr. Soil Sci. 2006, 169, 310-329. [CrossRef]

313. Street-Perrott, F.A.; Barker, P.A. Biogenic silica: A neglected component of the coupled global continental biogeochemical cycles of carbon and silicon. Earth Surf. Process. Landforms 2008, 33, 1436-1457. [CrossRef] 
314. Cornelis, J.T.; Delvaux, B.; Georg, R.B.; Lucas, Y.; Ranger, J.; Opfergelt, S. Tracing the origin of dissolved silicon transferred from various soil-plant systems towards rivers: A review. Biogeosciences 2011, 8, 89-112. [CrossRef]

315. Fraysse, F.; Cantais, F.; Pokrovsky, O.S.; Schott, J.; Meunier, J.D. Aqueous reactivity of phytoliths and plant litter: Physico-chemical constraints on terrestrial biogeochemical cycle of silicon. J. Geochem. Explor. 2006, 88, 202-205. [CrossRef]

316. Fraysse, F.; Pokrovsky, O.S.; Schott, J.; Meunier, J.D. Surface chemistry and reactivity of plant phytoliths in aqueous solutions. Chem. Geol. 2009, 258, 197-206. [CrossRef]

317. Dürr, H.H.; Meybeck, M.; Hartmann, J.; Laruelle, G.G.; Roubeix, V. Global spatial distribution of natural riverine silica inputs to the coastal zone. Biogeosciences 2011, 8, 597-620. [CrossRef]

318. Struyf, E.; Smis, A.; Van Damme, S.; Garnier, J.; Govers, G.; Van Wesemael, B.; Conley, D.J.; Batelaan, O.; Frot, E.; Clymans, W.; et al. Historical land use change has lowered terrestrial silica mobilization. Nat. Commun. 2010, 1, 129. [CrossRef]

319. Vandevenne, F.I.; Delvaux, C.; Hughes, H.J.; André, L.; Ronchi, B.; Clymans, W.; Baraõ, L.; Govers, G.; Meire, P.; Struyf, E. Landscape cultivation alters 830 Si signature in terrestrial ecosystems. Sci. Rep. 2015, 5, 7732. [CrossRef]

320. Vandevenne, F.I.; Barão, L.; Ronchi, B.; Govers, G.; Meire, P.; Kelly, E.F.; Struyf, E. Silicon pools in human impacted soils of temperate zones. Glob. Biogeochem. Cycles 2015, 9, 1439-1450. [CrossRef]

321. Clymans, W.; Struyf, E.; Govers, G.; Vandevenne, F.; Conley, D.J. Anthropogenic impact on amorphous silica pools in temperate soils. Biogeosciences 2011, 8, 2281-2293. [CrossRef]

322. Sommer, M.; Jochheim, H.; Höhn, A.; Breuer, J.; Zagorski, Z.; Busse, J.; Barkusky, D.; Meier, K.; Puppe, D.; Wanner, M.; et al. Si cycling in a forest biogeosystem-the importance of transient state biogenic Si pools. Biogeosciences 2013, 10, 4991-5007. [CrossRef]

323. Desplanques, V.; Cary, L.; Mouret, J.C.; Trolard, F.; Bourrié, G.; Grauby, O.; Meunier, J.D. Silicon transfers in a rice field in Camargue (France). J. Geochemical Explor. 2006, 88, 190-193. [CrossRef]

324. Guntzer, F.; Keller, C.; Poulton, P.R.; McGrath, S.P.; Meunier, J.D. Long-Term removal of wheat straw decreases soil amorphous silica at Broadbalk, Rothamsted. Plant Soil 2012, 352, 173-184. [CrossRef]

325. Meunier, J.D.; Guntzer, F.; Kirman, S.; Keller, C. Terrestrial plant-Si and environmental changes. Mineral. Mag. 2008, 72, $263-267$. [CrossRef]

326. Vandevenne, F.; Struyf, E.; Clymans, W.; Meire, P. Agricultural silica harvest: Have humans created a new loop in the global silica cycle? Front. Ecol. Environ. 2012, 10, 243-248. [CrossRef]

327. Schaller, J.; Puppe, D. Heat improves silicon availability in mineral soils. Geoderma 2021, 386, 114909. [CrossRef]

328. Haynes, R.J. What effect does liming have on silicon availability in agricultural soils? Geoderma 2019, 337, 375-383. [CrossRef]

329. Savant, N.K.; Snyder, G.H.; Datnoff, L.E. Silicon management and sustainable rice production. Adv. Agron. 1996, 58, 151-199. [CrossRef]

330. Savant, N.K.; Korndörfer, G.H.; Datnoff, L.E.; Snyder, G.H. Silicon nutrition and sugarcane production: A review. J. Plant Nutr. 1999, 22, 1853-1903. [CrossRef]

331. Berhane, M.; Xu, M.; Liang, Z.; Shi, J.; Wei, G.; Tian, X. Effects of long-term straw return on soil organic carbon storage and sequestration rate in North China upland crops: A meta-analysis. Glob. Chang. Biol. 2020, 26, 2686-2701. [CrossRef] [PubMed]

332. Li, H.; Dai, M.; Dai, S.; Dong, X. Current status and environment impact of direct straw return in China's cropland-A review. Ecotoxicol. Environ. Saf. 2018, 159, 293-300. [CrossRef]

333. Song, Z.; Müller, K.; Wang, H. Biogeochemical silicon cycle and carbon sequestration in agricultural ecosystems. Earth-Sci. Rev. 2014, 139, 268-278. [CrossRef]

334. Hodson, M.J. The relative importance of cell wall and lumen phytoliths in carbon sequestration in soil: A hypothesis. Front. Earth Sci. 2019, 7, 167. [CrossRef]

335. Caubet, M.; Cornu, S.; Saby, N.P.A.; Meunier, J.D. Agriculture increases the bioavailability of silicon, a beneficial element for crop, in temperate soils. Sci. Rep. 2020, 10, 19999. [CrossRef] [PubMed]

336. Puppe, D.; Kaczorek, D.; Schaller, J.; Barkusky, D.; Sommer, M. Crop straw recycling prevents anthropogenic desilication of agricultural soil-plant sys-tems in the temperate zone-Results from a long-term field experiment in NE Germany. Geoderma. in revision.

337. Kaczorek, D.; Puppe, D.; Busse, J.; Sommer, M. Effects of phytolith distribution and characteristics on extractable silicon fractions in soils under different vegetation-An exploratory study on loess. Geoderma 2019, 356, 113917. [CrossRef]

338. Cornelis, J.T.; Titeux, H.; Ranger, J.; Delvaux, B. Identification and distribution of the readily soluble silicon pool in a temperate forest soil below three distinct tree species. Plant Soil 2011, 342, 369-378. [CrossRef]

339. Puppe, D.; Ehrmann, O.; Kaczorek, D.; Wanner, M.; Sommer, M. The protozoic Si pool in temperate forest ecosystemsQuantification, abiotic controls and interactions with earthworms. Geoderma 2015, 243-244, 196-204. [CrossRef]

340. Haynes, R.J. Significance and role of Si in crop production. Adv. Agron. 2017, 146, 83-166. [CrossRef]

341. Puppe, D.; Sommer, M. Experiments, uptake mechanisms, and functioning of silicon foliar fertilization-A review focusing on maize, rice, and wheat. Adv. Agron. 2018, 152, 1-49. [CrossRef]

342. Klotzbücher, T.; Treptow, C.; Kaiser, K.; Klotzbücher, A.; Mikutta, R. Sorption competition with natural organic matter as mechanism controlling silicon mobility in soil. Sci. Rep. 2020, 10, 11225. [CrossRef] [PubMed]

343. Li, Z.; Guo, F.; Cornelis, J.T.; Song, Z.; Wang, X.; Delvaux, B. Combined silicon-phosphorus fertilization affects the biomass and phytolith stock of rice plants. Front. Plant Sci. 2020, 11, 67. [CrossRef] 
344. Miles, N.; Manson, A.D.; Rhodes, R.; van Antwerpen, R.; Weigel, A. Extractable silicon in soils of the South African sugar industry and relationships with crop uptake. Commun. Soil Sci. Plant Anal. 2014, 45, 2949-2958. [CrossRef]

345. Korndörfer, G.H.; Snyder, G.H.; Ulloa, M.; Powell, G.; Datnoff, L.E. Calibration of soil and plant silicon analysis for rice production. J. Plant Nutr. 2001, 24, 1071-1084. [CrossRef]

346. de Tombeur, F.; Vander Linden, C.; Cornélis, J.T.; Godin, B.; Compère, P.; Delvaux, B. Soil and climate affect foliar silicification patterns and silica-cellulose balance in sugarcane (Saccharum officinarum). Plant Soil 2020, 452, 529-546. [CrossRef]

347. Gocke, M.; Liang, W.; Sommer, M.; Kuzyakov, Y. Silicon uptake by wheat: Effects of Si pools and pH. J. Plant Nutr. Soil Sci. 2013, 176, 551-560. [CrossRef]

348. Marxen, A.; Klotzbücher, T.; Jahn, R.; Kaiser, K.; Nguyen, V.S.; Schmidt, A.; Schädler, M.; Vetterlein, D. Interaction between silicon cycling and straw decomposition in a silicon deficient rice production system. Plant Soil 2016, 398, 153-163. [CrossRef]

349. Keeping, M.G. Uptake of silicon by sugarcane from applied sources may not reflect plant-available soil silicon and total silicon content of sources. Front. Plant Sci. 2017, 8, 760. [CrossRef] [PubMed]

350. Saccone, L.; Conley, D.J.; Likens, G.E.; Bailey, S.W.; Buso, D.C.; Johnson, C.E. Factors that control the range and variability of amorphous silica in soils in the Hubbard Brook Experimental Forest. Soil Sci. Soc. Am. J. 2008, 72, 1637-1644. [CrossRef]

351. Fishkis, O.; Ingwersen, J.; Streck, T. Phytolith transport in sandy sediment: Experiments and modeling. Geoderma 2009, 151, 168-178. [CrossRef]

352. Fishkis, O.; Ingwersen, J.; Lamers, M.; Denysenko, D.; Streck, T. Phytolith transport in soil: A field study using fluorescent labelling. Geoderma 2010, 157, 27-36. [CrossRef]

353. Song, Z.; McGrouther, K.; Wang, H. Occurrence, turnover and carbon sequestration potential of phytoliths in terrestrial ecosystems. Earth-Sci. Rev. 2016, 158, 19-30. [CrossRef]

354. Maguire, T.J.; Templer, P.H.; Battles, J.J.; Fulweiler, R.W. Winter climate change and fine root biogenic silica in sugar maple trees (Acer saccharum): Implications for silica in the Anthropocene. J. Geophys. Res. Biogeosci. 2017, 122, 708-715. [CrossRef]

355. Turpault, M.P.; Calvaruso, C.; Kirchen, G.; Redon, P.O.; Cochet, C. Contribution of fine tree roots to the silicon cycle in a temperate forest ecosystem developed on three soil types. Biogeosciences 2018, 15, 2231-2249. [CrossRef]

356. Puppe, D.; Leue, M. Physicochemical surface properties of different biogenic silicon structures: Results from spectroscopic and microscopic analyses of protistic and phytogenic silica. Geoderma 2018, 330, 212-220. [CrossRef]

357. de Tombeur, F.; Turner, B.L.; Laliberté, E.; Lambers, H.; Mahy, G.; Faucon, M.P.; Zemunik, G.; Cornelis, J.T. Plants sustain the terrestrial silicon cycle during ecosystem retrogression. Science 2020, 369, 1245-1248. [CrossRef] [PubMed]

358. Hinsinger, P.; Plassard, C.; Tang, C.; Jaillard, B. Origins of root-mediated $\mathrm{pH}$ changes in the rhizosphere and their responses to environmental constraints: A review. Plant Soil 2003, 248, 43-59. [CrossRef]

359. Hinsinger, P.; Fernandes Barros, O.N.; Benedetti, M.F.; Noack, Y.; Callot, G. Plant-Induced weathering of a basaltic rock: Experimental evidence. Geochim. Cosmochim. Acta 2001, 65, 137-152. [CrossRef]

360. Gattullo, C.E.; Allegretta, I.; Medici, L.; Fijan, R.; Pii, Y.; Cesco, S.; Mimmo, T.; Terzano, R. Silicon dynamics in the rhizosphere: Connections with iron mobilization. J. Plant Nutr. Soil Sci. 2016, 179, 409-417. [CrossRef]

361. Puppe, D. Review on protozoic silica and its role in silicon cycling. Geoderma 2020, 365, 114224. [CrossRef]

362. Qin, Y.; Puppe, D.; Zhang, L.; Sun, R.; Li, P.; Xie, S. How does Sphagnum growing affect testate Amoeba communities and corresponding protozoic Si pools? Results from field analyses in SW China. Microb. Ecol. 2021. [CrossRef]

363. Qin, Y.; Puppe, D.; Payne, R.; Li, L.; Li, J.; Zhang, Z.; Xie, S. Land-Use change effects on protozoic silicon pools in the Dajiuhu National Wetland Park, China. Geoderma 2020, 368, 114305. [CrossRef]

364. Ehrlich, H.; Demadis, K.D.; Pokrovsky, O.S.; Koutsoukos, P.G. Modern views on desilicification: Biosilica and abiotic silica dissolution in natural and artificial environments. Chem. Rev. 2010, 110, 4656-4689. [CrossRef]

365. Haynes, R.J. A contemporary overview of silicon availability in agricultural soils. J. Plant Nutr. Soil Sci. 2014, 177, 831-844. [CrossRef]

366. Crusciol, C.A.C.; De Arruda, D.P.; Fernandes, A.M.; Antonangelo, J.A.; Alleoni, L.R.F.; Do Nascimento, C.A.C.; Rossato, O.B.; McCray, J.M. Methods and extractants to evaluate silicon availability for sugarcane. Sci. Rep. 2018, 8, 916. [CrossRef]

367. Mithen, S.; Jenkins, E.; Jamjoum, K.; Nuimat, S.; Nortcliff, S.; Finlayson, B. Experimental crop growing in Jordan to develop methodology for the identification of ancient crop irrigation. World Archaeol. 2008, 40, 7-25. [CrossRef]

368. Ma, J.; Nishimura, K.; Takahashi, E. Effect of silicon on the growth of rice plant at different growth stages. Soil Sci. Plant Nutr. 1989, 35, 347-356. [CrossRef]

369. Pati, S.; Pal, B.; Badole, S.; Hazra, G.C.; Mandal, B. Effect of silicon fertilization on growth, yield, and nutrient uptake of rice. Commun. Soil Sci. Plant Anal. 2016, 47, 284-290. [CrossRef]

370. Cuong, T.X.; Ullah, H.; Datta, A.; Hanh, T.C. Effects of silicon-based Fertilizer on growth, yield and nutrient uptake of rice in tropical zone of Vietnam. Rice Sci. 2017, 24, 283-290. [CrossRef]

371. Agostinho, F.B.; Tubana, B.S.; Martins, M.S.; Datnoff, L.E. Effect of different silicon sources on yield and silicon uptake of rice grown under varying phosphorus rates. Plants 2017, 6, 35. [CrossRef] [PubMed]

372. Seebold, K.W.; Datnoff, L.E.; Correa-Victoria, F.J.; Kucharek, T.A.; Snyder, G.H. Effect of silicon rate and host resistance on blast, scald, and yield of upland price. Plant Dis. 2000, 84, 871-876. [CrossRef]

373. Detling, J.K.; Painter, E.L. Defoliation responses of western wheatgrass populations with diverse histories of prairie dog grazing. Oecologia 1983, 57, 65-71. [CrossRef] [PubMed] 
374. McNaughton, S.J.; Tarrants, J.L.; McNaughton, M.M.; Davis, R.D. Silica as a defense against herbivory and a growth promotor in African grasses. Ecology 1985, 66, 528-535. [CrossRef]

375. Strömberg, C.A.E. Decoupled taxonomic radiation and ecological expansion of open-habitat grasses in the Cenozoic of North America. Proc. Natl. Acad. Sci. USA 2005, 102, 11980-11984. [CrossRef] [PubMed]

376. Strömberg, C.A.E.; Di Stilio, V.S.; Song, Z. Functions of phytoliths in vascular plants: An evolutionary perspective. Funct. Ecol. 2016, 30, 1286-1297. [CrossRef]

377. Kistler, L.; Haney, J.M.; Newsom, L.A. Experimental investigation of pathogenic stress on phytolith formation in Cucurbita pepo var. texana (wild gourd). Veg. Hist. Archaeobot. 2013, 22, 165-170. [CrossRef]

378. Wieczorek, M.; Zub, K.; Szafrańska, P.A.; Ksiazek, A.; Konarzewski, M. Plant-Herbivore interactions: Silicon concentration in tussock sedges and population dynamics of root voles. Funct. Ecol. 2015, 29, 187-194. [CrossRef]

379. Schuldt, A.; Ebeling, A.; Kunz, M.; Staab, M.; Guimarães-Steinicke, C.; Bachmann, D.; Buchmann, N.; Durka, W.; Fichtner, A.; Fornoff, F.; et al. Multiple plant diversity components drive consumer communities across ecosystems. Nat. Commun. 2019, 10, 1460. [CrossRef]

380. Schaller, J.; Roscher, C.; Hillebrand, H.; Weigelt, A.; Oelmann, Y.; Wilcke, W.; Ebeling, A.; Weisser, W.W. Plant diversity and functional groups affect $\mathrm{Si}$ and Ca pools in aboveground biomass of grassland systems. Oecologia 2016. [CrossRef]

381. Schaller, J.; Hodson, M.J.; Struyf, E. Is relative Si/Ca availability crucial to the performance of grassland ecosystems? Ecosphere 2017, 8, e01726. [CrossRef]

382. Conley, D.J.; Carey, J.C. Biogeochemistry: Silica cycling over geologic time. Nat. Geosci. 2015, 8, 431-432. [CrossRef]

383. Cornelis, J.T.; Ranger, J.; Iserentant, A.; Delvaux, B. Tree species impact the terrestrial cycle of silicon through various uptakes. Biogeochemistry 2010, 97, 231-245. [CrossRef]

384. Derry, L.A.; Kurtz, A.C.; Ziegler, K.; Chadwick, O.A. Biological control of terrestrial silica cycling and export fluxes to watersheds. Nature 2005, 433, 728-731. [CrossRef] [PubMed]

385. Müller, F.; Struyf, E.; Hartmann, J.; Wanner, A.; Jensen, K. A comprehensive study of silica pools and fluxes in Wadden Sea salt marshes. Estuaries Coasts 2013, 36, 1150-1164. [CrossRef]

386. Brackhage, C.; Schaller, J.; Bäucker, E.; Dudel, E.G. Silicon availability affects the stoichiometry and content of calcium and micro nutrients in the leaves of common reed. Silicon 2013, 5, 199-204. [CrossRef]

387. Hu, A.Y.; Xu, S.N.; Qin, D.N.; Li, W.; Zhao, X.Q. Role of silicon in mediating phosphorus imbalance in plants. Plants 2021, 10, 51. [CrossRef] [PubMed]

388. Minden, V.; Schaller, J.; Olde Venterink, H. Plants increase silicon content as a response to nitrogen or phosphorus limitation: A case study with Holcus lanatus. Plant Soil 2020. [CrossRef]

389. Nelwamondo, A.; Dakora, F.D. Silicon promotes nodule formation and nodule function in symbiotic cowpea (Vigna unguiculata). New Phytol. 1999, 142, 463-467. [CrossRef]

390. Dakora, F.D.; Le Roux, R. Phosphorus nutrition alters root flavonoid content, nitrogen fixation, and phosphorus partitioning in cowpea. In Nitrogen Fixation: Fundememntals and Applications; Tikhonovich, I.A., Provorov, N.A., Romanov, V.I., Newton, W.E., Eds.; Springer: Dordrecht, The Netherlands, 1995; p. 324.

391. Teixeira, G.C.M.; de Mello Prado, R.; Rocha, A.M.S.; de Cássia Piccolo, M. Root- and foliar-applied silicon modifies C: N: P ratio and increases the nutritional efficiency of pre-sprouted sugarcane seedlings under water deficit. PLoS ONE 2020, 15, e0240847. [CrossRef]

392. Frazão, J.J.; de Mello Prado, R.; de Souza Júnior, J.P.; Rossatto, D.R. Silicon changes C:N:P stoichiometry of sugarcane and its consequences for photosynthesis, biomass partitioning and plant growth. Sci. Rep. 2020, 10, 12492. [CrossRef] [PubMed]

393. Hao, Q.; Yang, S.; Song, Z.; Li, Z.; Ding, F.; Yu, C.; Hu, G.; Liu, H. Silicon affects plant stoichiometry and accumulation of C, N, and $\mathrm{P}$ in grasslands. Front. Plant Sci. 2020, 11, 1304. [CrossRef] [PubMed]

394. Schaller, J.; Struyf, E. Silicon controls microbial decay and nutrient release of grass litter during aquatic decomposition. Hydrobiologia 2013, 709, 201-212. [CrossRef]

395. Schaller, J.; Hines, J.; Brackhage, C.; Bäucker, E.; Gessner, M.O. Silica decouples fungal growth and litter decomposition without changing responses to climate warming and N enrichment. Ecology 2014, 95, 3181-3189. [CrossRef]

396. Das, S.; Lee, J.G.; Cho, S.R.; Song, H.J.; Kim, P.J. Silicate fertilizer amendment alters fungal communities and accelerates soil organic matter decomposition. Front. Microbiol. 2019, 10, 2950. [CrossRef] [PubMed]

397. Emsens, W.J.; Schoelynck, J.; Grootjans, A.P.; Struyf, E.; van Diggelen, R. Eutrophication alters Si cycling and litter decomposition in wetlands. Biogeochemistry 2016, 130, 289-299. [CrossRef]

398. Hömberg, A.; Broder, T.; Knorr, K.H.; Schaller, J. Divergent effect of silicon on greenhouse gas production from reduced and oxidized peat organic matter. Geoderma 2021, 386, 114916. [CrossRef]

399. Hömberg, A.; Obst, M.; Knorr, K.H.; Kalbitz, K.; Schaller, J. Increased silicon concentration in fen peat leads to a release of iron and phosphate and changes in the composition of dissolved organic matter. Geoderma 2020, 374, 114422. [CrossRef]

400. Song, Z.; Liu, H.; Strömberg, C.A.E.; Yang, X.; Zhang, X. Phytolith carbon sequestration in global terrestrial biomes. Sci. Total Environ. 2017, 603, 502-509. [CrossRef]

401. Ji, Z.; Yang, X.; Song, Z.; Liu, H.; Liu, X.; Qiu, S.; Li, J.; Guo, F.; Wu, Y.; Zhang, X. Silicon distribution in meadow steppe and typical steppe of northern China and its implications for phytolith carbon sequestration. Grass Forage Sci. 2018, 73, 482-492. [CrossRef] 
402. Li, Z.; Song, Z.; Cornelis, J.T. Impact of rice cultivar and organ on elemental composition of phytoliths and the release of bio-available silicon. Front. Plant Sci. 2014, 5, 529. [CrossRef] [PubMed]

403. Parr, J.; Sullivan, L.; Chen, B.; Ye, G.; Zheng, W. Carbon bio-sequestration within the phytoliths of economic bamboo species. Glob. Chang. Biol. 2010, 16, 2661-2667. [CrossRef]

404. Schaller, J.; Heimes, R.; Ma, J.F.; Meunier, J.D.; Shao, J.F.; Fujii-Kashino, M.; Knorr, K.H. Silicon accumulation in rice plant aboveground biomass affects leaf carbon quality. Plant Soil 2019, 444, 399-407. [CrossRef]

405. Song, Z.; Wang, H.; Strong, P.J.; Li, Z.; Jiang, P. Plant impact on the coupled terrestrial biogeochemical cycles of silicon and carbon: Implications for biogeochemical carbon sequestration. Earth-Sci. Rev. 2012, 115, 319-331. [CrossRef]

406. Carter, J.A. Atmospheric carbon isotope signatures in phytolith-occluded carbon. Quat. Int. 2009, 193, 20-29. [CrossRef]

407. Asscher, Y.; Weiner, S.; Boaretto, E. A new method for extracting the insoluble occluded carbon in archaeological and modern phytoliths: Detection of $14 \mathrm{C}$ depleted carbon fraction and implications for radiocarbon dating. J. Archaeol. Sci. 2017, 78, 57-65. [CrossRef]

408. Causey, G.W. Cytological investigations with the electron microscope. Ann. R. Coll. Surg. Engl. 1958, $22,43-53$.

409. Alexandre, A.; Balesdent, J.; Cazevieille, P.; Chevassus-Rosset, C.; Signoret, P.; Mazur, J.C.; Harutyunyan, A.; Doelsch, E.; Basile-Doelsch, I.; Miche, H.; et al. Direct uptake of organically derived carbon by grass roots and allocation in leaves and phytoliths: 13C labeling evidence. Biogeosciences 2016, 13, 1693-1703. [CrossRef]

410. Alexandre, A.; Basile-Doelsch, I.; Delhaye, T.; Borshneck, D.; Mazur, J.C.; Reyerson, P.; Santos, G.M. New highlights of phytolith structure and occluded carbon location: 3-D X-ray microscopy and NanoSIMS results. Biogeosciences 2015, 12, 863-873. [CrossRef]

411. dos Santos, G.M. Comment on Atmospheric carbon isotope signatures in phytolith occluded carbon, Carter, J.A., Quaternary International, this volume. Quat. Int. 2009, 193, 30-31. [CrossRef]

412. Santos, G.M.; Alexandre, A.; Southon, J.R.; Treseder, K.K.; Corbineau, R.; Reyerson, P.E. Possible source of ancient carbon in phytolith concentrates from harvested grasses. Biogeosciences 2012, 9, 1873-1884. [CrossRef]

413. Santos, G.M.; Alexandre, A.; Coe, H.H.G.; Reyerson, P.E.; Southon, J.R.; De Carvalho, C.N. The phytolith 14c puzzle: A tale of background determinations and accuracy tests. Radiocarbon 2010, 52, 113-128. [CrossRef]

414. Santos, G.M.; Alexandre, A. The phytolith carbon sequestration concept: Fact or fiction? A comment on “Occurrence, turnover and carbon sequestration potential of phytoliths in terrestrial ecosystems by Song et al. doi:10.1016/j.earscirev.2016.04.007". Earth-Sci. Rev. 2017, 164, 251-255. [CrossRef]

415. Reyerson, P.E.; Alexandre, A.; Harutyunyan, A.; Corbineau, R.; De La Torre, H.A.M.; Badeck, F.; Cattivelli, L.; Santos, G.M. Unambiguous evidence of old soil carbon in grass biosilica particles. Biogeosciences 2016, 13, 1269-1286. [CrossRef]

416. Elbaum, R.; Melamed-Bessudo, C.; Tuross, N.; Levy, A.A.; Weiner, S. New methods to isolate organic materials from silicified phytoliths reveal fragmented glycoproteins but no DNA. Quat. Int. 2009, 193, 11-19. [CrossRef]

417. Song, Z.; Liu, C.; Müller, K.; Yang, X.; Wu, Y.; Wang, H. Silicon regulation of soil organic carbon stabilization and its potential to mitigate climate change. Earth-Sci. Rev. 2018, 185, 463-475. [CrossRef]

418. Song, Z.; Liu, H.; Li, B.; Yang, X. The production of phytolith-occluded carbon in China's forests: Implications to biogeochemical carbon sequestration. Glob. Chang. Biol. 2013, 19, 2907-2915. [CrossRef] [PubMed]

419. Song, Z.; Liu, H.; Si, Y.; Yin, Y. The production of phytoliths in China's grasslands: Implications to the biogeochemical sequestration of atmospheric CO 2. Glob. Chang. Biol. 2012, 18, 3647-3653. [CrossRef]

420. Friedlingstein, P.; Jones, M.W.; O'Sullivan, M.; Andrew, R.M.; Hauck, J.; Peters, G.P.; Peters, W.; Pongratz, J.; Sitch, S.; Le Quéré, C.; et al. Global carbon budget 2019. Earth Syst. Sci. Data 2019, 11, 1783-1838. [CrossRef]

421. Fraysse, F.; Pokrovsky, O.S.; Meunier, J.D. Experimental study of terrestrial plant litter interaction with aqueous solutions. Geochim. Cosmochim. Acta 2010, 74, 70-84. [CrossRef]

422. Exley, C. Silicon in life:A bioinorganic solution to bioorganic essentiality1JD Birchall memorial lecture.1. J. Inorg. Biochem. 1998, 69, 139-144. [CrossRef]

423. Ikegami, N.; Satake, T.; Nagayama, Y.; Inubushi, K. Changes in silica in litterfall and available silica in the soil of forests invaded by bamboo species (Phyllostachys pubescens and P. bambusoides) in western Japan. Soil Sci. Plant Nutr. 2014, 60, 731-739. [CrossRef]

424. Borrelli, N.; Alvarez, M.F.; Osterrieth, M.L.; Marcovecchio, J.E. Silica content in soil solution and its relation with phytolith weathering and silica biogeochemical cycle in Typical Argiudolls of the Pampean Plain, Argentina-a preliminary study. J. Soils Sediments 2010, 10, 983-994. [CrossRef]

425. Cabanes, D.; Shahack-Gross, R. Understanding fossil phytolith preservation: The role of partial dissolution in paleoecology and archaeology. PLoS ONE 2015, 10, e0125532. [CrossRef] [PubMed]

426. Cabanes, D.; Weiner, S.; Shahack-Gross, R. Stability of phytoliths in the archaeological record: A dissolution study of modern and fossil phytoliths. J. Archaeol. Sci. 2011, 38, 2480-2490. [CrossRef]

427. Butterfield, N.J. Animals and the invention of the Phanerozoic Earth system. Trends Ecol. Evol. 2011, 26, 81-87. [CrossRef]

428. Pausas, J.G.; Bond, W.J. On the three major recycling pathways in terrestrial ecosystems. Trends Ecol. Evol. 2020, 35, 767-775. [CrossRef] [PubMed]

429. Callaway, R.M.; Kikodze, D.; Chiboshvili, M.; Khetsuriani, L. Unpalatable plants protect neighbors from grazing and increase plant community diversity. Ecology 2005, 86, 1856-1862. [CrossRef] 
430. Gabay, O.; Perevolotsky, A.; Bar Massada, A.; Carmel, Y.; Shachak, M. Differential effects of goat browsing on herbaceous plant community in a two-phase mosaic. Plant Ecol. 2011, 212, 1643-1653. [CrossRef]

431. Hadar, L.; Noy-Meir, I.; Perevolotsky, A. The effect of shrub clearing and grazing on the composition of a Mediterranean plant community: Functional groups versus species. J. Veg. Sci. 1999, 10, 673-682. [CrossRef]

432. Díaz, S.; Lavorel, S.; McIntyre, S.; Falczuk, V.; Casanoves, F.; Milchunas, D.G.; Skarpe, C.; Rusch, G.; Sternberg, M.; Noy-Meir, I.; et al. Plant trait responses to grazing-A global synthesis. Glob. Chang. Biol. 2007, 13, 313-341. [CrossRef]

433. Fernández Honaine, M.; Osterrieth, M.L.; Zucol, A.F. Plant communities and soil phytolith assemblages relationship in native grasslands from southeastern Buenos Aires province, Argentina. Catena 2009, 76, 89-96. [CrossRef]

434. Shahack-Gross, R. Herbivorous livestock dung: Formation, taphonomy, methods for identification, and archaeological significance. J. Archaeol. Sci. 2011, 38, 205-218. [CrossRef]

435. Shahack-Gross, R.; Finkelstein, I. Subsistence practices in an arid environment: A geoarchaeological investigation in an Iron Age site, the Negev Highlands, Israel. J. Archaeol. Sci. 2008, 35, 965-982. [CrossRef]

436. Shahack-Gross, R.; Boaretto, E.; Cabanes, D.; Katz, O.; Finkelstein, I. Subsistence economy in the Negev Highlands: The iron age and the byzantine/ early islamic period. Levant 2014, 46, 98-117. [CrossRef]

437. Shahack-Gross, R.; Marshall, F.; Ryan, K.; Weiner, S. Reconstruction of spatial organization in abandoned Maasai settlements: Implications for site structure in the Pastoral Neolithic of East Africa. J. Archaeol. Sci. 2004, 31, 1395-1411. [CrossRef]

438. Delhon, C.; Martin, L.; Argant, J.; Thiébault, S. Shepherds and plants in the Alps: Multi-proxy archaeobotanical analysis of neolithic dung from "La Grande Rivoire" (Isère, France). J. Archaeol. Sci. 2008, 35, 2937-2952. [CrossRef]

439. Johansen, P.G. Landscape, monumental architecture, and ritual: A reconsideration of the South Indian ashmounds. J. Anthropol. Archaeol. 2004, 23, 309-330. [CrossRef]

440. Tsartsidou, G.; Lev-Yadun, S.; Efstratiou, N.; Weiner, S. Ethnoarchaeological study of phytolith assemblages from an agro-pastoral village in Northern Greece (Sarakini): Development and application of a Phytolith Difference Index. J. Archaeol. Sci. 2008, 35, 600-613. [CrossRef]

441. Shahack-Gross, R.; Albert, R.M.; Gilboa, A.; Nagar-Hilman, O.; Sharon, I.; Weiner, S. Geoarchaeology in an urban context: The uses of space in a Phoenician monumental building at Tel Dor (Israel). J. Archaeol. Sci. 2005, 32, 1417-1431. [CrossRef]

442. Katz, O. Plant silicon and phytolith research and the earth-life superdiscipline. Front. Plant Sci. 2018, 9, 1281. [CrossRef] [PubMed]

443. Schuiling, R.D.; Krijgsman, P. Enhanced weathering: An effective and cheap tool to sequester $\mathrm{CO}_{2}$. Clim. Chang. 2006, 74, 349-354. [CrossRef]

444. Falkowski, P.G.; Katz, M.E.; Knoll, A.H.; Quigg, A.; Raven, J.A.; Schofield, O.; Taylor, F.J.R. The evolution of modern eukaryotic phytoplankton. Science 2004, 305, 354-360. [CrossRef]

445. Bergvall, U.A.; Rautio, P.; Kesti, K.; Tuomi, J.; Leimar, O. Associational effects of plant defences in relation to within- and between-patch food choice by a mammalian herbivore: Neighbour contrast susceptibility and defence. Oecologia 2006, 147, 253-260. [CrossRef]

446. Wheeler, J.A.; Schnider, F.; Sedlacek, J.; Cortés, A.J.; Wipf, S.; Hoch, G.; Rixen, C. With a little help from my friends: Community facilitation increases performance in the dwarf shrub Salix herbacea. Basic Appl. Ecol. 2015, 16, 202-209. [CrossRef]

447. Berendse, F.; Scheffer, M. The angiosperm radiation revisited, an ecological explanation for Darwin's "abominable mystery". Ecol. Lett. 2009, 12, 865-872. [CrossRef] [PubMed]

448. Augusto, L.; Davies, T.J.; Delzon, S.; de Schrijver, A. The enigma of the rise of angiosperms: Can we untie the knot? Ecol. Lett. 2014, 17, 1326-1338. [CrossRef] [PubMed] 